\title{
Diurnally resolved particulate and VOC measurements at a rural site: indication of significant biogenic secondary organic aerosol formation
}

\author{
S. J. Sjostedt ${ }^{1,2}$, J. G. Slowik ${ }^{1,3}$, J. R. Brook ${ }^{2}$, R. Y.-W. Chang ${ }^{1}$, C. Mihele $^{2}$, C. A. Stroud ${ }^{2}$, A. Vlasenko ${ }^{1,2}$, and \\ J. P. D. Abbatt ${ }^{1}$ \\ ${ }^{1}$ Department of Chemistry, University of Toronto, Toronto, ON, M5S 3H6, Canada \\ ${ }^{2}$ Environment Canada, Science and Technology Branch, Toronto, ON, M3H 5T4, Canada \\ ${ }^{3}$ Paul Scherrer Institut, Villigen, Switzerland
}

Received: 5 October 2010 - Published in Atmos. Chem. Phys. Discuss.: 11 November 2010

Revised: 25 May 2011 - Accepted: 31 May 2011 - Published: 21 June 2011

\begin{abstract}
We report simultaneous measurements of volatile organic compound (VOC) mixing ratios including $\mathrm{C}_{6}$ to $\mathrm{C}_{8}$ aromatics, isoprene, monoterpenes, acetone and organic aerosol mass loadings at a rural location in southwestern Ontario, Canada by Proton-Transfer-Reaction Mass Spectrometry (PTR-MS) and Aerosol Mass Spectrometry (AMS), respectively. During the three-week-long Border Air Quality and Meteorology Study in June-July 2007, air was sampled from a range of sources, including aged air from the polluted US Midwest, direct outflow from Detroit $50 \mathrm{~km}$ away, and clean air with higher biogenic input. After normalization to the diurnal profile of $\mathrm{CO}$, a long-lived tracer, diurnal analyses show clear photochemical loss of reactive aromatics and production of oxygenated VOCs and secondary organic aerosol (SOA) during the daytime. Biogenic VOC mixing ratios increase during the daytime in accord with their light- and temperature-dependent sources. Long-lived species, such as hydrocarbon-like organic aerosol and benzene show little to no photochemical reactivity on this timescale. From the normalized diurnal profiles of VOCs, an estimate of $\mathrm{OH}$ concentrations during the daytime, measured $\mathrm{O}_{3}$ concentrations, and laboratory SOA yields, we calculate integrated local organic aerosol production amounts associated with each measured SOA precursor. Under the assumption that biogenic precursors are uniformly distributed across the southwestern Ontario location, we conclude that such precursors contribute significantly to the total amount of SOA formation, even dur-
\end{abstract}

Correspondence to: S. J. Sjostedt (steve.sjostedt@ec.gc.ca) ing the period of Detroit outflow. The importance of aromatic precursors is more difficult to assess given that their sources are likely to be localized and thus of variable impact at the sampling location.

\section{Introduction}

Although ozone and particulate matter have been historically viewed as two independent criteria for characterizing air quality, it is now recognized that there is a tight relationship between them. In particular, it is well known that oxidation of volatile organic compounds (VOCs) leads to tropospheric ozone production. Under close scrutiny of late is the coupled role that photochemistry and VOCs play in the production of secondary organic aerosol (SOA) (Seinfeld and Pankow, 2003; Kroll and Seinfeld, 2008; de Gouw and Jimenez, 2009; Hallquist et al., 2009).

The oxidation of VOCs is initiated by reaction with atmospheric radicals, and by ozone in the case of olefins (Atkinson and Arey, 2003). During the day the primary oxidant is the hydroxyl radical $(\mathrm{OH})$ and, in the presence of sunlight and $\mathrm{NO}_{\mathrm{x}}$ the products go on to form ozone and oxygenated volatile organic compounds (OVOCs). OVOCs can be further oxidized to form multi-functional-group species, including carboxylic acids. Thus, the oxidation of VOCs can lead to a reduction of vapor pressure relative to the precursor molecule due to the addition of polar functional groups. The decrease in vapor pressure can be offset by a reduction in the length of the carbon backbone by carbon-carbon bond cleavage, since the vapor pressure of larger compounds is less than

Published by Copernicus Publications on behalf of the European Geosciences Union. 
that of smaller ones. However, should the oxidation of the parent VOC ultimately lead to a substantial decrease in the vapor pressure and decomposition does not occur to a sizable degree, the products can then go into the condensed phase to form secondary organic aerosol (SOA) (Pankow, 1994). Formation of an oxygenated product of sufficiently low vapor pressure may require multiple generations of oxidation products. Whether the oxidation products ultimately end up as an aerosol depends on several factors such as the structure of the parent compound, the composition of the aerosol and the $\mathrm{NO}_{\mathrm{x}}$ concentration. Low $\mathrm{NO}_{\mathrm{x}}$ environments may be more conducive to SOA production due to the formation of low vapor pressure organic peroxides from reaction with $\mathrm{HO}_{2}$ (Kroll and Seinfeld, 2008; de Gouw and Jimenez, 2009; Hallquist et al., 2009). Also, note that SOA formation may occur in the aqueous phase via condensed-phase processes, such as those driven by carbonyl uptake.

To assess the degree of SOA formation via gas phase oxidation and subsequent condensation that might have occurred over a specific region a standard approach is to incorporate organic aerosol laboratory yields, i.e. the amount of SOA formed from a specific VOC precursor under a prescribed set of conditions in a large reaction chamber, into a chemical transport model that includes spatially resolved VOC emission fluxes, gas-phase chemistry, horizontal and vertical air transport, gas and particle deposition, etc. (Chen et al., 2006; Kleeman et al., 2007; Murphy and Pandis, 2009). This approach is taken in the paper by Stroud et al. (2011) that is part of this special issue, using Environment Canada's AURAMS chemical transport model (Gong et al., 2003; Stroud et al., 2008; Makar et al., 2009).

Here, we present a novel measurement-based approach where we match the degree of chemical loss of diurnally averaged SOA precursors to the simultaneous measurement of oxygenated organic aerosol formation. This allows us to assess the degree to which the measured VOCs contribute to the total SOA formed locally. Carbon monoxide is used to normalize for dynamical effects, particularly associated with the changing height of the boundary layer (de Gouw et al., 2009). The advantage of this method is that both the VOC precursor and organic aerosol amounts are directly measured, without the need for an emissions model. The only external information required is the yield of SOA from specific VOC precursors and the rate constants for radical-driven loss of the VOCs, both of which can be taken from laboratory experiments described in the literature. Uncertainties to this approach are also important to point out, the most significant of which is that the measurements are from only one location whereas SOA formation occurs over a wider geographic extent. For that reason, we emphasize that the SOA formation rate calculations are for just the observation location; a chemical transport model is necessary to assess SOA formation regionally.

To illustrate this analysis approach we use measurements taken during the Boundary Air Quality and Meteorology
Study (BAQS-Met), an air quality study during the summer of 2007 involving Environment Canada, academic researchers, and the Ontario Ministry of the Environment. The overall goal of BAQS-Met was to evaluate the degree to which pollution in southwestern Ontario is influenced by long-range transport or formed locally, and by complex meteorology that prevails across many areas due to the high frequency of lake breezes associated with the Great Lakes.

For this paper, a specific goal was to assess the relative degree to which different VOC precursors contributed to SOA formation at a rural location - Harrow, Ontario - using the analysis approach outlined above. Although VOCs of both biogenic and anthropogenic origin are known to be important in the formation of SOA, the magnitude of each contribution remains an open question (de Gouw et al., 2005, 2008; Heald et al., 2005; Volkamer et al., 2006; Kleinman et al., 2007). Past studies in polluted environments have had difficulty obtaining closure between the amount of SOA formed and that predicted by models. Agreement in biogenic regimes has been better of late (Capes et al., 2009; Slowik et al., 2010). Harrow provides a locale that is influenced by both local and regional biogenic sources and anthropogenically impacted air that is photochemically fresh (when from Detroit, Michigan) and aged (when from the Ohio Valley). As such, we focus on the relative degree to which biogenic sources contribute to the local rates of SOA formation relative to aromatic (i.e. anthropogenic) precursors for this location. Finally, we perform an initial comparison of our results to those from the AURAMS chemical transport model.

\section{Experimental}

\subsection{BAQS-Met field campaign}

Measurements were conducted from mid June through early July 2007 at the Agriculture Canada field site at Harrow (Fig. 1). Harrow is a small farming community in southwestern Ontario that can be influenced by air flow from Detroit $(\sim 50 \mathrm{~km} \mathrm{NW})$, the Ohio Valley $(\sim 400 \mathrm{~km} \mathrm{SW})$ as well as by local biogenic sources. The shores of Lake Erie are $5 \mathrm{~km}$ to the south. The measurement site was in a field, about $100 \mathrm{~m}$ from a two-lane rural highway, i.e. removed from major local particle sources. A major four-lane highway was located about $30 \mathrm{~km}$ to the north. For the most part the three week study was conducted under dry conditions, with three notable exceptions. There was measurable rainfall during the afternoon of 27 June, the pre-dawn hours of 4 July and the afternoon and evening of 5 July. None of these periods was greater than eight hours in length. A small number of VOC measurements are reported of BTEX from a Windsor sampling site, which is part of the Windsor/Detroit metropolitan region, and from Bear Creek, a rural site on the shores of Lake St. Clair located about $50 \mathrm{~km}$ east of Detroit and roughly the same distance northeast of Harrow (Fig. 1). 


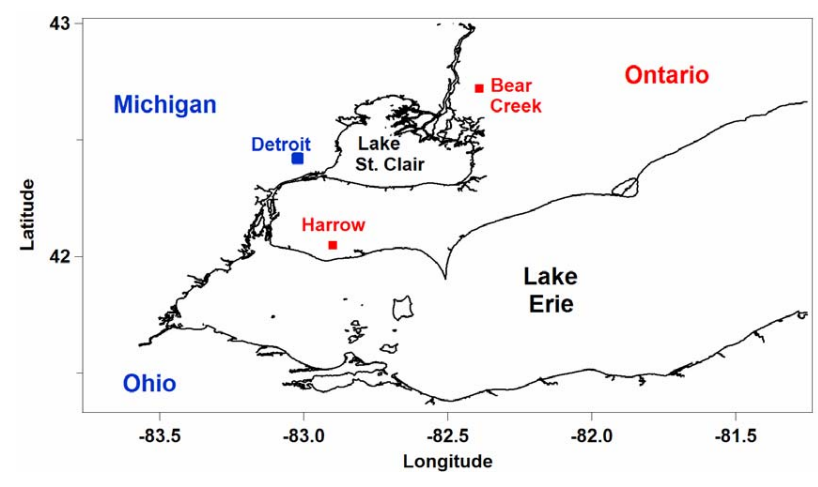

Fig. 1. Harrow, $\mathrm{ON}$ and the surrounding area.

\subsection{Measurements}

Volatile organic compounds (VOCs) levels were measured using a proton-transfer reaction mass spectrometer (PTRMS) (Lindinger et al., 1998; de Gouw and Warneke, 2007) (Ionicon Analytik). In the PTR-MS, $\mathrm{H}_{3} \mathrm{O}^{+}$ions generated by a discharge in water vapor ionize trace gases that have a higher proton affinity than water. The resulting ions are detected with a quadrupole mass spectrometer. Because this soft ionization technique causes relatively little fragmentation, measured mass-to-charge ratios can frequently be directly related to the parent ion, and so VOCs can be identified to some degree. Species with the same molecular weight, such as the xylenes and ethylbenzene cannot be distinguished. The same is true with all the monoterpenes, and with methyl vinyl ketone and methacrolein, that yield signal at the same mass-to-charge ratio.

The PTR-MS was calibrated with a custom standard that contained, amongst other species: acetone, isoprene, methyl vinyl ketone, benzene, toluene, and $\alpha$-pinene in the $500 \mathrm{ppbv}$ range (Apel-Riemer Environmental Inc., USA). Speciesdependent calibration factors and detection limits, along with the activated charcoal backgrounding method and sample line details, are described in detail elsewhere (Vlasenko et al., 2009). For this study the sample line inlet was at $3 \mathrm{~m}$ above the ground. The mass spectrometer was operated in full scan mode with data points collected across the full mass range $(m / z, 21-160)$ every $140 \mathrm{~s}$.

Please refer to Levy et al. (2010), which is part of this special issue, for details on the measurements of $\mathrm{CO}, \mathrm{O}_{3}$, and $\mathrm{SO}_{2}$. BTEX measurements from Windsor and Bear Creek were analyzed using the methods from Wang et al. (2005).

A compact time-of-flight aerosol mass spectrometer (CToF AMS, Aerodyne Inc., USA) measured the composition of the non-refractory component of submicron aerosol. The non-refractory component is empirically defined as species that are vaporizable over a roughly $1 \mathrm{~s}$ time interval at $870 \mathrm{~K}$ and $10^{-7}$ torr. AMS operating principles are described elsewhere (Drewnick et al., 2005; Jayne et al., 2000; Jimenez et al., 2003) while operation and analysis procedures during the present study are described in a paper in this special issue (Slowik et al., 2011).

\subsection{PMF analysis of the organic aerosol mass spectra}

Positive Matrix Factorization (Paatero and Tapper, 1994; Paatero, 1997) was applied to the organic aerosol mass spectral data using the PMF2 software package (P. Paatero, U. of Helsinki, Finland) in robust mode, together with the CU AMS PMF Tool (Ulbrich et al., 2009). Details of the PMF are given in Slowik et al. (2011). As described in that paper, the best PMF solution consisted of four factors, which we label HOA (hydrocarbon-like organic aerosol), OOA-1, OOA2 (oxygenated organic aerosol, types 1 and 2) and Factor 4. Briefly, the HOA factor is thought to arise from primary anthropogenic emissions and has a mass spectrum characteristic of aliphatic hydrocarbons. The OOA-1 and OOA-2 factors are more oxygenated; using the empirical relationship between the fraction of organic signal occurring at $\mathrm{m} / \mathrm{z} 44$ $\left(\mathrm{CO}_{2}^{+}\right.$ion $)$and the molecular O:C ratio derived by Aiken et al. (2008), we estimate O:C values of $\sim 0.96$ and $\sim 0.50$ for OOA-1 and OOA-2, respectively. The OOA-1 and OOA2 mass spectra are similar to those of low-volatility OOA (LV-OOA) and semivolatile OOA (SV-OOA), respectively (Jimenez et al., 2009). It is likely that OOA-1 represents the less volatile and more aged SOA fraction. Factor 4 (also referred to as the UNKN factor in Slowik et al., 2011), was only a minor component of the organic aerosol except at the end of the study, when winds shifted to a moderate, steady south/southwest flow. The $\mathrm{CO}_{2}^{+}$ion $(\mathrm{m} / \mathrm{z} 44)$ intensity constitutes only 0.01 of its spectrum, suggesting a low O:C ratio. This factor coincides with a period of high isoprene and low aromatics, suggesting a biogenic influence, and a sulfate plume from Midwestern US locations. Taken together, these observations suggest the Factor 4 may be due to uptake of fresh biogenic VOCs onto preexisting sulfate aerosol or reactive uptake of isoprene, but we recognize this is highly speculative (see Slowik et al., 2011 and its interactive discussion).

\subsection{AURAMS model}

AURAMS is an off-line chemical transport model that is driven by the Canadian operational weather forecast model, GEM. AURAMS was run in a one way nested configuration with a continental scale outer domain at $42 \mathrm{~km}$ grid spacing, an inner regional domain at $15 \mathrm{~km}$ grid spacing, and a highresolution domain at $2.5 \mathrm{~km}$ grid spacing. Hourly anthropogenic emission files were prepared for AURAMS using the 2005 Canadian and 2005 US emissions inventories. Further details about the biogenic emission algorithms (BEIS v3.09) and the organic chemistry mechanism in AURAMS can be found in Slowik et al. (2010). 


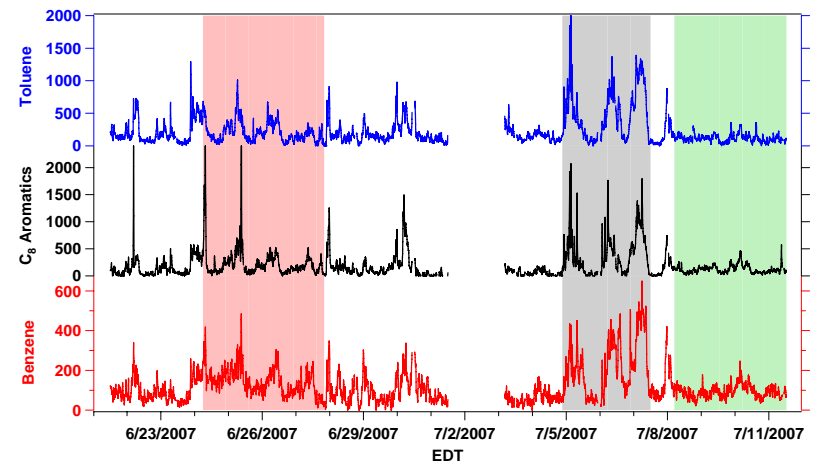

Fig. 2. Aromatic VOC time series, as measured by the PTR-MS. Units are in pptv. Red, black and green shaded periods refers to different air mass episodes: Processed Air, Detroit Air, and Sulfate and Biogenic Air, respectively.

\section{Results and discussion}

\subsection{Diurnal profiles for the full campaign}

The full gas-phase data set has been broken down into three specific groups for analysis. Aromatics, which consists of benzene, toluene, and $\mathrm{C}_{8}$ aromatics (xylenes + ethyl benzene), are species of anthropogenic origin with variable chemical lifetimes. Biogenics are comprised of relatively short-lived (i.e. lifetimes less than a day) chemicals directly emitted from foliage, such as the monoterpenes and isoprene as well as the 1st generation oxidation products of isoprene, methacrolein (MACR) and methyl vinyl ketone (MVK). The final group is comprised of acetone and ozone, which are relatively longer-lived oxygenates primarily produced photochemically from the processing of both biogenic and anthropogenic VOC precursors. To this group we add carbon monoxide $(\mathrm{CO})$ as a tracer species that is longer lived than the above species and sulfur dioxide $\left(\mathrm{SO}_{2}\right)$ as a primary pollutant from industrial fossil fuel combustion. Time series of the mixing ratios of these species are in Figs. 2, 3 and 4.

The aerosol data have been divided into two subsets. The first delineates the sub-micron aerosol mass arising from organics and the inorganic species, sulfate $\left(\mathrm{SO}_{4}^{2-}\right)$, nitrate $\left(\mathrm{NO}_{3}^{-}\right)$and ammonium $\left(\mathrm{NH}_{4}^{+}\right)$. The second shows the organic aerosol factors that have been derived from the PMF analysis. There are four factors that arise, as described in the previous section. These time series are in Fig. 5.

The measurements exhibit consistent diurnal profiles for both the gas phase species and aerosol composition. As is commonly recognized, such diurnal changes in observed values can be attributed to both chemistry and dynamical effects, such as changes in the boundary layer height that occur over the course of a $24 \mathrm{~h}$ day. To account as best as possible for these dynamical effects, the diurnally averaged signals for each species are normalized to $\mathrm{CO}$, given that it is a long-lived chemical tracer. This technique is used widely,

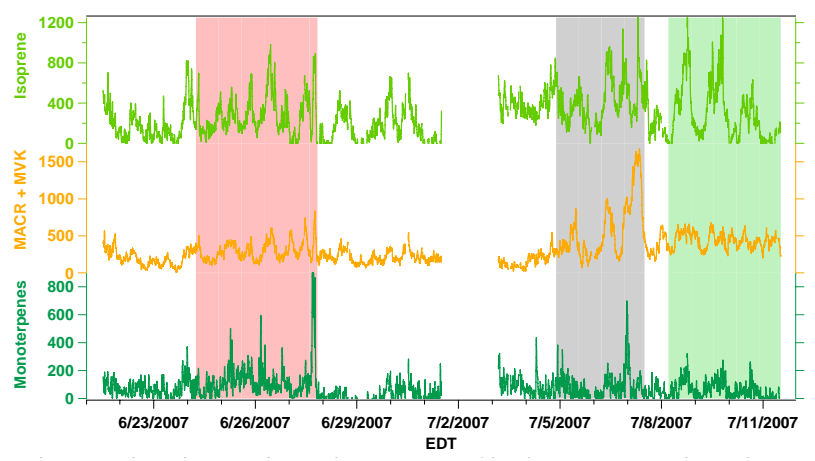

Fig. 3. Biogenic VOC time series, as measured by the PTR-MS. Units are in pptv. Red, black and green shaded periods refers to different air mass episodes: Processed Air, Detroit Air, and Sulfate and Biogenic Air, respectively.

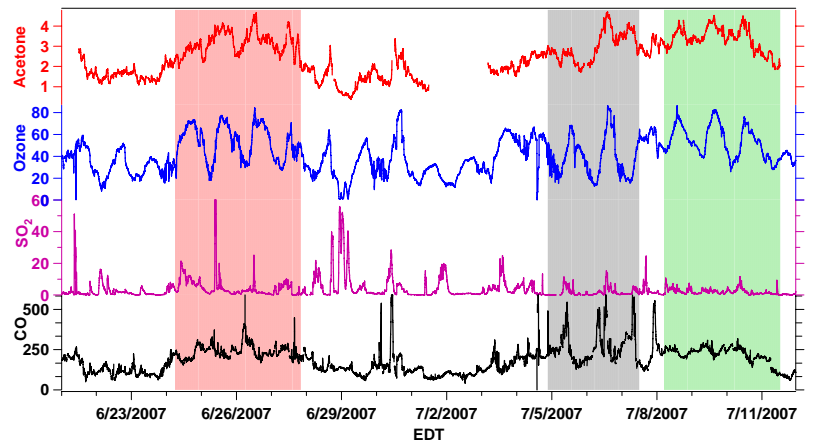

Fig. 4. Selected gas species time series. Acetone was measured by the PTR-MS, whereas the others by standard air quality measurement instruments. Units are in ppbv. Red, black and green shaded periods refers to different air mass episodes: Processed Air, Detroit Air, and Sulfate and Biogenic Air, respectively.

for example by de Gouw et al. (2009) where it was applied to both gas and aerosol data from the MILAGRO campaign in Mexico City. In our case, a background concentration of $80 \mathrm{ppbv}$ was assumed for the Northern Hemisphere around the summer solstice (Parrish et al., 2004; Li et al., 2004). We assume the background is pervasive throughout the atmosphere, and so we normalize to the mixing ratios of $\mathrm{CO}$ less this background value. We recognize that this approach inherently assumes that species above the boundary layer scale with $\mathrm{CO}$ in a linear manner, i.e. that use of $\mathrm{CO}$ can account for mixing of species from the free troposphere to the boundary layer. This approach will not be able to account for situations where, for example, there is considerable vertical structure to the SOA-CO relationship. However, as illustrated in the Supplementary Information, there were Twin Otter flights that studied southwestern Ontario air as a part of the BAQS-met campaign. The vertical structure of the averaged measurements of the flights indicates no vertical bias in the OA-CO relationship. Nevertheless, to gain some sense 

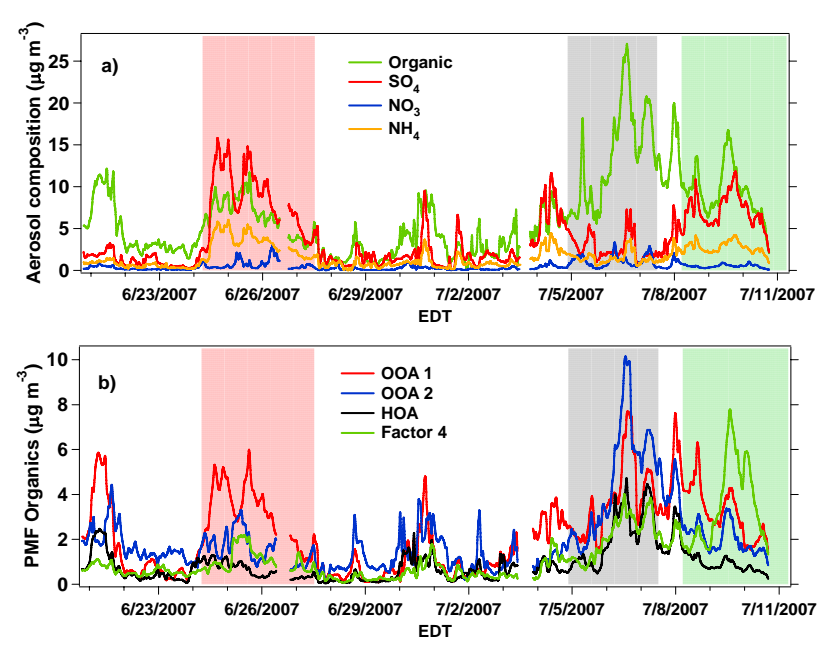

Fig. 5. Time Series of AMS species in the upper frame. Factors from the Positive Matrix Factorization of the AMS organics are shown in the lower frame. Red, black and green shaded periods refers to different air mass episodes: Processed Air, Detroit Air, and Sulfate and Biogenic Air, respectively.

for how normalization to $\mathrm{CO}$ affects the quantities presented in this paper, we present both data and calculations with and without $\mathrm{CO}$ normalization.

The diurnal profile of $\mathrm{CO}$ at Harrow during the study is shown in Fig. 6, where it is seen that mixing ratios rise throughout the night, indicative of relatively local emissions occurring into an increasingly shallow boundary layer. During the time of afternoon heating the mixing ratios are smallest due to mixing within a deeper boundary layer. (Note that for this diurnal profile, and for all others in the paper, we do a 21-point running average of all data, where the average is the arithmetic mean.) We acknowledge that $\mathrm{CO}$ could be impacted by short episodes of high anthropogenic input and/or a diurnal profile in the rate of local CO production that can be of biogenic or anthropogenic origin. However, these effects are minimized by our location, which is largely removed from major local sources of pollution, and by averaging data across the full campaign period.

After $\mathrm{CO}$ normalization, the aromatics (Fig. 7) exhibit a consistent pre-dawn peak and, for toluene and the $\mathrm{C}_{8}$ species, an afternoon minimum that extends from about 12:00 to 19:00 EDT. Such a pattern is consistent with chemical species whose source is direct emission and whose primary oxidant is the hydroxyl radical. After normalization, benzene mixing ratios remain constant throughout the day, consistent with the relatively long chemical lifetime of this species. Note that the flat diurnal profile for benzene provides added support that the normalization to the $\mathrm{CO}$ diurnal variation is a justifiable approach for decoupling boundary layer mixing from chemical loss processes, for the primary anthropogenic VOCs at least.
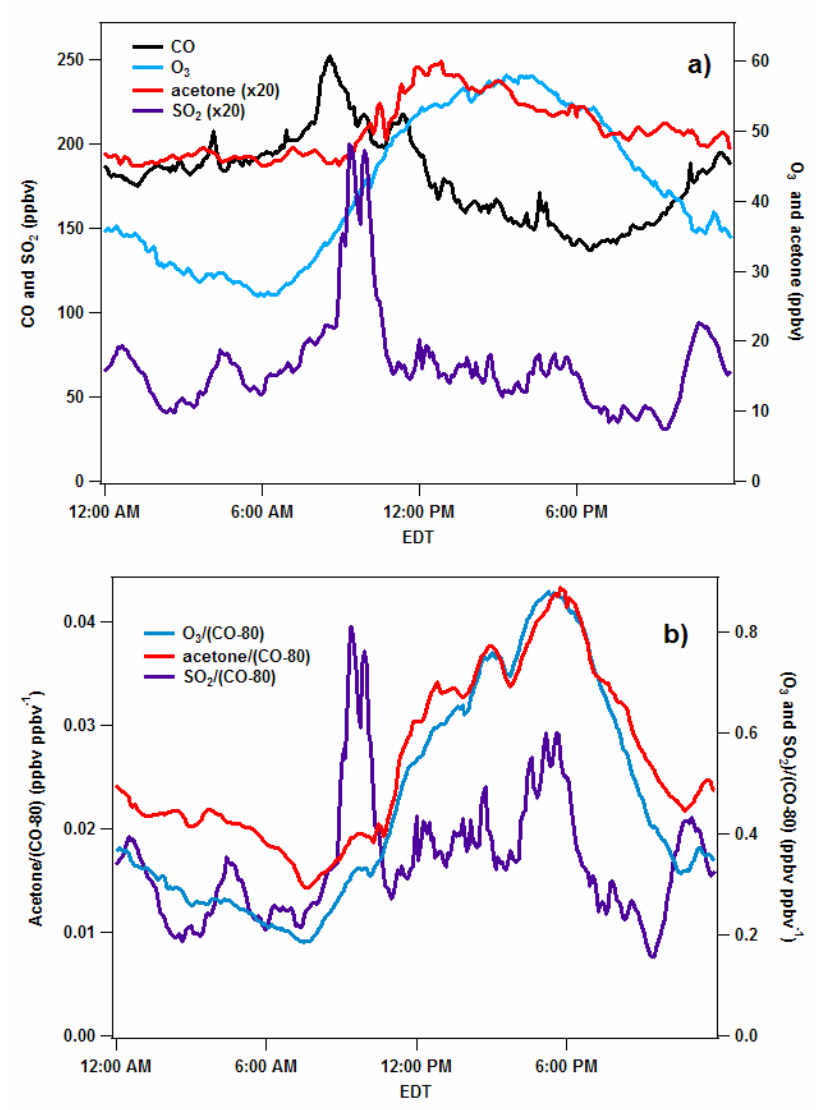

Fig. 6. Diurnal profiles of selected trace gases, with (b) and without (a) normalization to $\mathrm{CO}$ less its regional background value.

Conversely, secondary chemical species that are formed from photochemistry such as acetone, ozone and PTR-MS formaldehyde (not shown) display an enhancement during the afternoon hours (see Fig. 6). The peak, with normalization to the boundary layer, is around 18:00 EDT. The diurnal profiles of acetone and ozone are quite similar to each other, indicating that both are photochemically produced and that both have relatively long chemical lifetimes. The biogenic species (isoprene and MVK/MACR) also peak in the late afternoon (Fig. 7). Qualitatively, the profiles are consistent with enhanced isoprene emissions during the day and with subsequent loss via reaction with $\mathrm{OH}$, although the isoprene signals likely arise from more local emissions than those of the longer-lived oxidation products. It is somewhat surprising that MVK/MACR does not peak after isoprene, perhaps due to transport effects, e.g. downward transport of these species during the day. The release of monoterpenes is dependent on temperature and thus the early evening maximum is likely due to local emissions and decreasing $\mathrm{OH}$ as the sun sets.

The concentrations of the aerosol species also displayed prominent diurnal profiles (Fig. 8). Over the entire campaign organic matter constituted the largest fraction $(\sim 50 \%)$ of the sub-micron aerosol mass, as is common with a large number 

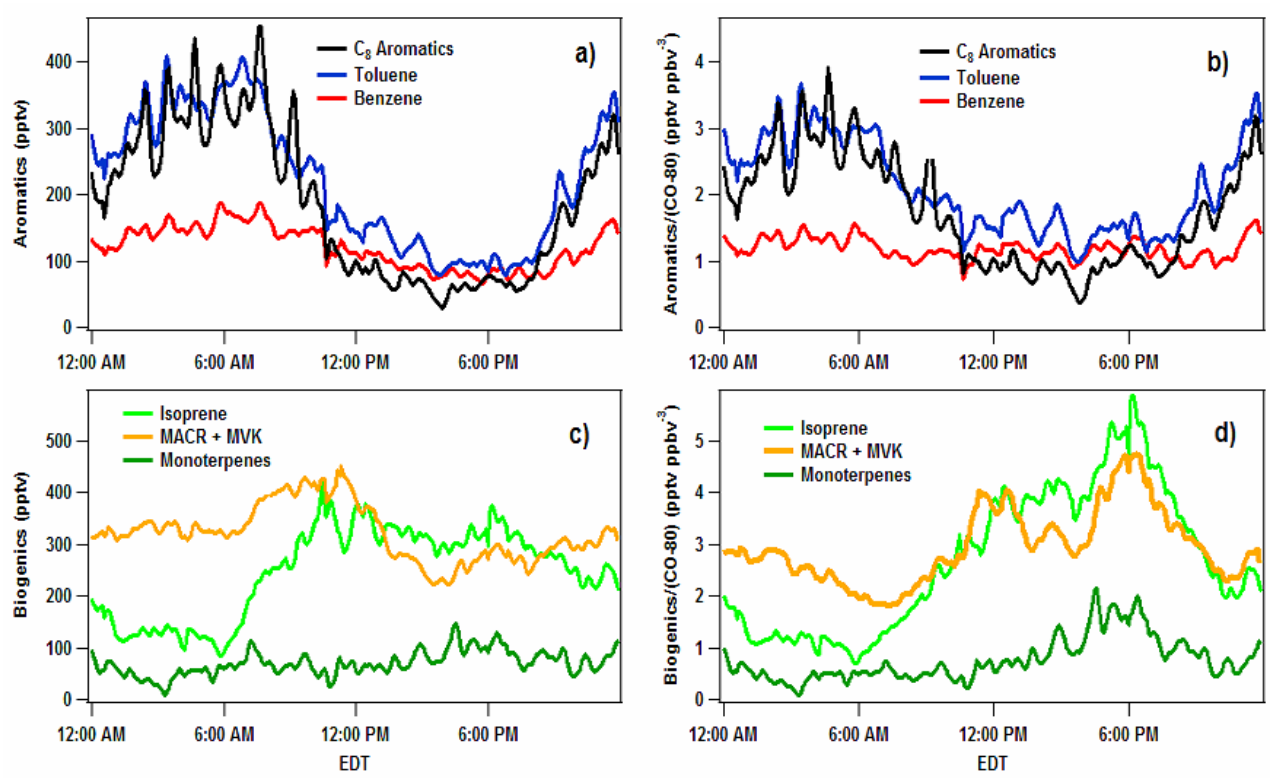

Fig. 7. Diurnal profiles of aromatics (upper frames, $\mathbf{a}$ and $\mathbf{b}$ ) and biogenic species (lower frames, $\mathbf{c}$ and $\mathbf{d}$ ), without normalization to CO less its regional background value (left frames, $\mathbf{a}$ and $\mathbf{c}$ ) and with normalization (right frames, $\mathbf{b}$ and $\mathbf{d}$ ).
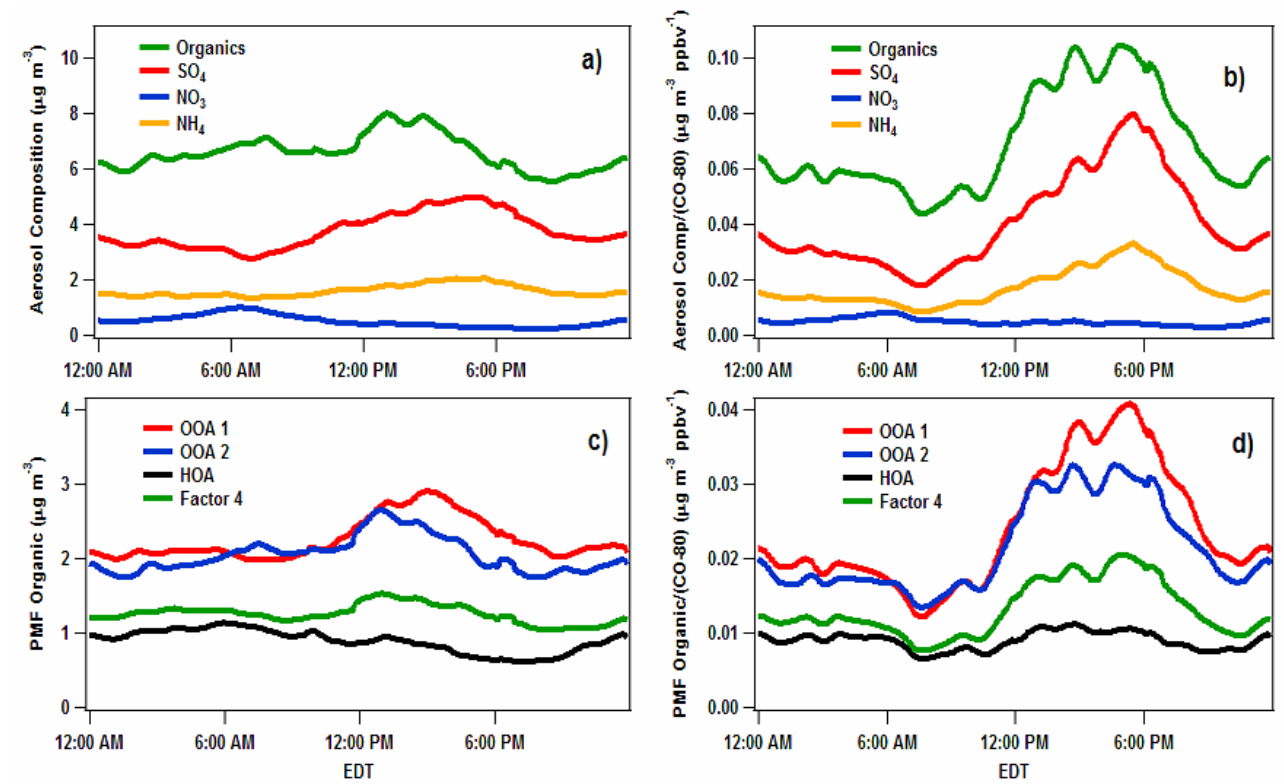

Fig. 8. Diurnal profiles of AMS species (upper frames, a and b) and AMS organic PMF factors (lower frames, $\mathbf{c}$ and $\mathbf{d}$ ), without normalization to $\mathrm{CO}$ less its regional background value (left frames, $\mathbf{a}$ and $\mathbf{c}$ ) and with normalization (right frames, $\mathbf{b}$ and $\mathbf{d}$ ).

of sites worldwide (Zhang et al., 2007). Of the remaining half of the particulate matter, the majority was contributed by sulfate followed by ammonium and nitrate. The organics and sulfate displayed a prominent daytime enhancement, similar to that of $\mathrm{O}_{3}$ and acetone, indicative of photochemical formation of each species, whereas the nitrate profile was enhanced early in the morning and reached a minimum in the afternoon. The nitrate profile is likely affected by a variety of factors, such as accumulation of $\mathrm{HNO}_{3}$ at night arising from $\mathrm{N}_{2} \mathrm{O}_{5}$ hydrolysis and by low temperatures of night that preferentially partition nitrate to particulates and the warm daytime temperatures which do not allow nitrate to persist. The sulfate afternoon maximum will be driven by photochemistry, arising from gas-phase oxidation of $\mathrm{SO}_{2}$ to form $\mathrm{H}_{2} \mathrm{SO}_{4}$, which either partitions to pre-existing particles or participates in new particle formation. 
As described above, the organic aerosol fraction was broken down into four factors by Positive Matrix Factorization. Briefly, HOA is representative of primary, hydrocarbon-like emissions, whereas OOA-1 and OOA-2 both represent oxidized organic aerosol, with the former more oxygenated than the latter. Factor 4 is associated with a significant fraction of the total organic mass only during the last three days of the campaign.

With diurnal analysis (Fig. 8), the normalized profiles show that the amounts of aerosol mass attributed to the two oxygenated factors and to Factor 4 rise in the afternoon when photochemistry is most active. OOA-1 reaches its peak value somewhat later than OOA-2, consistent with it arising from oxidation of OOA-2 components and being more oxidized. Both factors rise in value at the same time just before 12:00 EDT. Conversely, HOA remains relatively unchanged throughout the 24-h day, much like the long-lived aromatic species, benzene. We interpret this to indicate that the timescale for heterogeneous or photochemical oxidation of HOA chemical components into volatile products or into a more oxygenated factor is longer than a few hours.

\subsection{Campaign episodes}

Although this paper focuses primarily on the overall behavior observed during the BAQS campaign at Harrow, a variety of air mass types were prevalent during the full campaign. To demonstrate this, we illustrate three distinct periods (see shaded regions in Figs. 2 to 5). Please refer to Slowik et al. (2011) for an analysis of the nature and transformation of the organic aerosol during specific campaign periods.

The first period is from 06:00 EDT on 24 June until 16:00 EDT on 27 June, during which the acetone levels are especially high while the $\mathrm{C}_{8}$ aromatics are not. Winds were generally out of the southwest. Furthermore, the tolueneto-benzene ratio, a marker of photochemical aging (Roberts et al., 1984), is also low (mean value $=1.4$ ), indicative of photochemically processed air. In the aerosol phase, sulfate was the dominant species by mass, although substantial organics were present. This period is referred to as Processed Air, which we believe arrived from the US Midwest by passing over Lake Erie without recent significant anthropogenic VOC input. In particular, the fetch from the north shore of Lake Erie is quite short, only a few $\mathrm{km}$, to the observation site over farmland. Temperatures were also elevated with air flow from the south. During the Processed Air period OOA1 was the largest organic PMF component, generally consistent with the view that OOA1 is indicative of highly aged, oxidatively processed air.

The second period, from midnight on 5 July until 12:00 EDT on 7 July, was dominated by winds out of the northwest, in the direction of Detroit. As such, this period is referred to as Detroit Air. In contrast to the Processed Air the aromatic mixing ratios reached their highest mixing ratios during this period. Also, the toluene to benzene ratio (mean $=2.4$ ) was higher indicating that Harrow was influenced by fresher anthropogenic emissions. In the aerosol phase the highest organic mass loading occurred at this time and there was little sulfate. During the Detroit Air plume, the OOA2 factor, less oxygenated than OOA1, is more dominant, consistent with new SOA formation.

The final period, from 05:00 EDT on 8 July until the end of the campaign, looks similar to the processed air in that the toluene-to-benzene ratio is diminished (mean $=1.4$ ). This period is distinguished from the Processed Air period by the extremely low aromatic signals and the enhanced mixing ratios of isoprene, which reached their peak values during this time. There is a steady wind flow from the southwest-west and the temperatures are high. As the sulfate levels are elevated at times, we refer to this period as Sulfate and Biogenic Air, and we believe it is characterized by aged air to which fresh biogenic emissions have been injected. PMF Factor 4 is attributed to the majority of the organic aerosol mass during this period.

We now examine diurnal profiles of the selected time periods. Whereas diurnal profiles for a full three week campaign are expected to give some average representation of the nature of the air at the site, we anticipate that average diurnal profiles over short time periods of a few days will not be as smooth due to more prominent interference by specific events. Nevertheless, qualitatively, the results are expected to provide valuable insight into the atmospheric processes involved.

In particular, in Fig. 9, the diurnal profiles of the OOA1 factor during these different episodes are all roughly the same, with similar timing and amounts of organic aerosol formed during the day. During the Processed Air event, the increase in OOA-1 levels is more than a factor of two higher than that of OOA-2 formed, whereas the amount of OOA-2 formation is similar to the amount of OOA-1 formation during Detroit Air. It appears as though there are similar levels of OOA-1 precursors (and oxidants) present in all the sampled air masses suggesting that OOA-1 formation occurs in a highly regional manner, whereas the levels of OOA-2 precursors are significantly enhanced during the polluted episode of Detroit Air. This is consistent with the higher levels of aromatics measured at that time, and perhaps unmeasured, semivolatile VOCs (Robinson et al., 2007), that are likely to also form OOA-2.

\subsection{Relationship of VOCs to SOA formation}

The goal in this section is to assess the relative degree to which specific VOCs lead to SOA formation. The approach we take uses the data from Sect. 3.1 where diurnal profiles were presented for the whole campaign. We attempt to quantitatively connect the integrated loss rate of VOCs to the total formation of organic aerosol mass. We also perform the same analysis on the full campaign period without the Detroit Air period, to assess the importance of this outflow time to the 

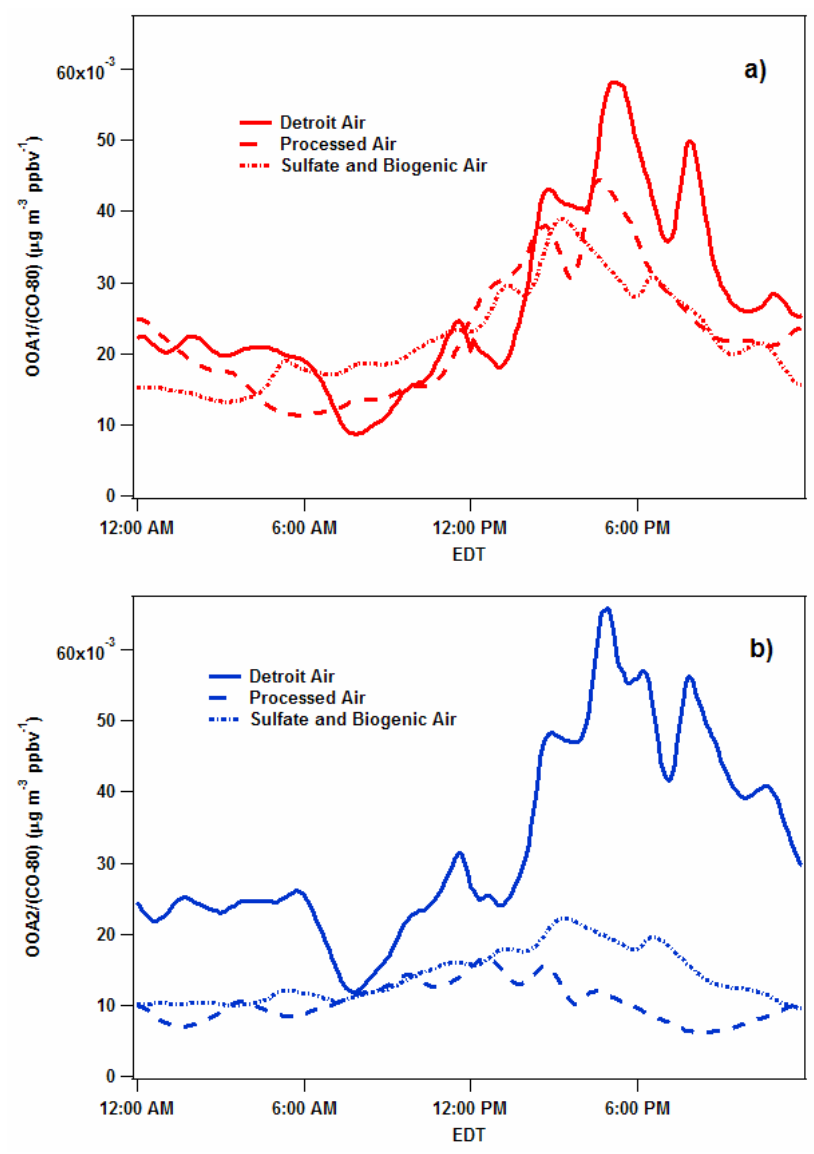

Fig. 9. Diurnal profiles of CO-normalized AMS PMF factors during selected episodes of the campaign: OOA1-upper frame, OO2-lower frame.

overall campaign. Also, we present results for just the Detroit Air period.

Specifically, the approach we take is to calculate the integrated production rate of $\mathrm{SOA}(\triangle \mathrm{SOA})$ due to $\mathrm{OH}$ oxidation according to:

$\Delta \mathrm{SOA}=\int_{0}^{T} k_{\mathrm{VOC}+\mathrm{Oxid}} Y[\mathrm{VOC}][$ Oxidant $] d t$

where $Y$ is the yield of SOA from a specific VOC precursor, $k_{\mathrm{VOC}+\mathrm{Oxid}}$ is the gas-phase rate constant for reaction of the VOC with either $\mathrm{O}_{3}$ or $\mathrm{OH}$, [Oxidant] is either the $\mathrm{OH}$ or $\mathrm{O}_{3}$ concentration at time $t$, and [VOC] is the VOC concentration at time $t$. Appropriate unit conversions are performed so that $\triangle \mathrm{SOA}$ is expressed in $\mu \mathrm{g} \mathrm{m}^{-3}$. In practice we approximate the integral of Eq. (1) as a summation, with time steps of $5 \mathrm{~min}$. We recognize that the quantity $\triangle \mathrm{SOA}$ represents the total production of SOA over a time period $T$ under the assumption that the $\mathrm{OH}$ and VOC concentrations, and the SOA yield, are the same at locations upwind of the observation site, i.e. that the local production rate as calculated by Eq. (1) at Harrow is constant over a spatial extent corresponding to the distance traveled by a gas-phase pre- cursor during its chemical lifetime. While clearly a major assumption, we believe that uncertainties that may arise are diminished by the use of average diurnal behavior across the full campaign time period plus the fact that the environs close to Harrow are all similar, with small sections of forest interspersed amongst agricultural land. Thus, we expect that this assumption will be more valid for biogenic precursors that will have more spatially uniform emission sources. For aromatics, however, where the sources will be more localized, greater uncertainties may arise. In particular, this approach does not account for very short-lived species that contribute to SOA formation upwind of Harrow but are not measured at the site. These issues are discussed in greater detail below.

We now discuss how each of the terms in Eq. (1) was obtained. First, the laboratory yields of SOA from a variety of VOC precursors have been studied extensively in numerous chamber experiments. For example, for the aromatics, studies (e.g. Hurley et al., 2001; Jang and Kamens, 2001; Ng et al., 2007b; Hildebrandt et al., 2009) have measured yields with many showing high $\mathrm{NO}_{\mathrm{x}}$ levels leading to lower SOA yields. Biogenic precursors have also been studied (e.g. Kroll et al., 2006; Ng et al., 2007a; Kleindienst et al., 2009) and a $\mathrm{NO}_{\mathrm{x}}$ dependence has also been observed in some cases. For use in Eq. (1), we have chosen to use the following yields: (i) for the aromatics we take the two-product parameters from (Ng et al., 2007b) for high $\mathrm{NO}_{\mathrm{x}}$ conditions and the massindependent yields from the same paper for low $\mathrm{NO}_{\mathrm{x}}$ conditions. Note that for the two-product cases, yields are assessed using the organic mass present at a specific time step in the summation, (ii) for isoprene, for high $\mathrm{NO}_{\mathrm{x}}$, we use the average yield from Experiments 9, 11 and 12 in Kroll et al. (2006) given that the organic mass loading in those experiments is close to the average organic aerosol mass during BAQS. For low $\mathrm{NO}_{\mathrm{x}}$, we take the two-product parameters from Henze and Seinfeld (2006), and (iii) for the monoterpenes, we consider both $\mathrm{OH}$ oxidation and ozonolysis. For ozonolysis, we have employed the two-product parameters from Shilling et al. (2008). Note that we assume that $\alpha$-pinene constitutes all of the PTR-MS monoterpene signal. Separating the contributions of ozone and hydroxyl radicals to SOA formation from monoterpenes in chamber studies is non trivial. In $\mathrm{Ng}$ et al. (2007a) the authors explicitly change $\mathrm{OH}$ sources from $\mathrm{HOOH}$ to HONO to examine the effect of $\mathrm{NO}_{\mathrm{x}}$. This leads to a low $\mathrm{NO}_{\mathrm{x}} \mathrm{SOA}$ yield of $38 \%$ and high $\mathrm{NO}_{\mathrm{x}} \mathrm{SOA}$ yield of $7 \%$ (Experiments 1 and 4 from Table 2 of $\mathrm{Ng}$ et al.). The authors acknowledge that in the low $\mathrm{NO}_{\mathrm{x}}$ experiments $30 \mathrm{ppbv}$ of $\mathrm{O}_{3}$ is formed and up to $35 \%$ of the SOA observed during peak formation may be attributable to ozonlysis. Even taking the contribution of ozone into account the yield of monoterpene $\mathrm{OH}$ oxidation in a low $\mathrm{NO}_{\mathrm{x}}$ environment provides the dominant SOA source on a molar basis. By contrast, a recent study (Hao et al., 2011) utilizing oxidant modulation indicates that $\mathrm{OH}$ oxidation products were $20-50 \%$ more volatile than ozonolysis products although the authors note that the $\mathrm{OH}$ oxidation products may undergo further oxidation that 
could lead to a higher SOA yield. We have decided to use the high $\mathrm{NO}_{\mathrm{x}}$ yield from $\mathrm{Ng}$ et al., and a $25 \%$ low $\mathrm{NO}_{\mathrm{x}}$ yield that takes into account the ozonolysis contribution.

Second, the gas-phase rate constant between $\mathrm{OH}$ and the VOC is taken directly from Atkinson et al. (2006), calculated for the field temperature conditions. In the case of the $\mathrm{C}_{8}$ aromatics, with the PTR-MS signal possibly arising from the three different xylenes and also from ethyl benzene, we weight the rate constants for the four individual species by the typical relative mixing ratios for these species measured in tunnel emission studies (Schauer et al., 1999, 2002).

Third, the VOC concentrations are taken directly from the time-resolved, diurnally averaged VOC mixing ratios measured at Harrow.

Finally, given that $\mathrm{OH}$ concentrations were not measured at Harrow, we estimate the amount of $\mathrm{OH}$ present near the observation site by following the approach published by de Gouw et al. (2009) who evaluated the average amount of $\mathrm{OH}$ present in Mexico City during the MILAGRO field campaign. We refer the reader to this paper for additional details. Briefly, noting that the loss of $\mathrm{C}_{8}$ aromatics and toluene is due to $\mathrm{OH}$ chemistry, we use the following expression:

$$
\begin{aligned}
& \frac{\left[\text { Aromatic }_{0}\right]-\left[\text { Aromatic }_{T}\right]}{\left[\text { Aromatic }_{0}\right]} \\
& =A\left(1-\exp \left(-k_{\text {Aromatic }+\mathrm{OH}}\left[\overline{\mathrm{OH}}_{\text {est }} \Delta t\right)\right)\right.
\end{aligned}
$$

This expression is the integrated rate equation for loss of aromatics due to $\mathrm{OH}$ chemistry over a time period $\Delta t$ extending from an initial time 0 to time $T$. The factor $A$ takes into account that aromatics may be emitted locally during the day and are not lost to reaction with $\mathrm{OH}$, i.e. the value of $A$ would be unity if there were no local daytime emissions. Its value can be determined empirically by noting that the most reactive $\mathrm{C}_{8}$ aromatics, i.e. the xylenes and ethyl benzene, reach a steady minimum value early in the afternoon that extends through to early evening.

For this work, we estimate the average $\mathrm{OH}$ concentration, $\overline{[\mathrm{OH}}_{\text {est }}$, that extends from 06:00 EDT to 18:00 EDT, corresponding to the total time over which there is loss of aromatics observed, i.e. the aromatic mixing ratios rise after 18:00 EDT due to decreasing $\mathrm{OH}$ and continued aromatic emissions. Thus, we set $T=12 \mathrm{~h}$. We choose the $A$ factor from the $\mathrm{C}_{8}$ aromatic time series, i.e. the most reactive aromatics, as the minimum value within a five-hour window about 15:00 EDT. At this time, the aromatic mixing ratio is 0.28 of its starting value (i.e. as a one-hour average centered at 06:00 EDT), representing an $A$ value of 0.72 . The average $\mathrm{OH}$ concentration was then calculated from Eq. (2) for both the $\mathrm{C}_{8}$ aromatic and the toluene data, yielding an average value of $3.6 \times 10^{6}$ molecules $\mathrm{cm}^{-3}$. Specifically, this is a measure of the average $\mathrm{OH}$ concentration at the Harrow site over the $12 \mathrm{~h}$ window from 06:00 EDT to 18:00 EDT. We do not believe this value is accurate to more than a factor of two given the uncertainties involved in its calculation. As an example, if we choose, instead, the $A$ factor from the value for the $\mathrm{C}_{8}$ aromatics for a one-hour window around 18:00 EDT, i.e. the end period of the minimum plateau reached by the aromatics, we arrive instead at a value for $A=0.61$. In this case, the average $\mathrm{OH}$ concentration across the 12 -h window is estimated to be $6.7 \times 10^{6}$ molecules $\mathrm{cm}^{-3}$. On the other hand, we know that the $A$ value is not unity. In particular, there certainly are local emissions of aromatics during the day because the $\mathrm{C}_{8}$ aromatic signal reaches its minimum value so close to noon. If there were no local emissions, the PTR-MS signal for these species would continue to drop throughout the afternoon hours when $\mathrm{OH}$ concentrations are high.

To accurately implement Eq. (1), we require time resolved $\mathrm{OH}$ concentrations, whereas the above calculation yields only a 12-h average. To determine the average $\mathrm{OH}$ concentrations in each 5-min interval we scale the time-resolved $\mathrm{OH}$ concentrations calculated from the averaged results of the AURAMS model that was run for the Harrow study time period to give the average concentration from the 06:00 EDT to 18:00 EDT time period that was determined above. A diurnal profile of $\mathrm{OH}$ concentration is shown in the Supplement.

The results from the calculation of the integrated and $\mathrm{CO}$ normalized SOA formation amounts during the entire campaign are presented in Table 1, where we include values under both high and low $\mathrm{NO}_{\mathrm{x}}$ conditions. Also included in the table are the observed increases in the AMS organic aerosol amount from the same time period, as deduced from Fig. 8. In particular, we estimate the increase of organic aerosol amount by taking the difference between one hour averages about the minimum and maximum values observed diurnally. Finally, we include the contribution to the SOA that may arise from ozonolysis of monoterpenes calculated using Eq. (1) with measured ozone concentrations, and the appropriate rate constant (Atkinson et al., 2006) and laboratory secondary aerosol yields for $\alpha$-pinene (Shilling et al., 2008), specifically, two-product fits for data with measured aerosol densities. We note that with no $\mathrm{HO}_{2}$ measurements at Harrow, it is difficult to determine whether SOA formation was proceeding in a high or low $\mathrm{NO}_{\mathrm{x}}$ regime. Specifically, a key step in the reaction mechanism that leads to condensable organics is thought to be the loss of the $\mathrm{RO}_{2}$ radical that is formed after initial $\mathrm{OH}$ attack on the VOC precursor and subsequent $\mathrm{O}_{2}$ addition. The $\mathrm{RO}_{2}$ species can react either with peroxy radicals, principally $\mathrm{HO}_{2}$, or with NO. Without $\mathrm{HO}_{2}$ measurements, we include in Table 1 SOA formation by $\mathrm{OH}$ oxidation under conditions of both high and low $\mathrm{NO}_{\mathrm{x}}$, as specified by the different yields measured in laboratory experiments.

The results are also presented graphically as a function of time-of-day SOA production amounts per $5 \mathrm{~min}$ time bin, where the time-dependent contributions to the overall SOA formation can be assessed (Fig. 10). In Tables 2-3, results for equivalent calculations are presented for: (i) the Detroit Air episode only, and (ii) the full campaign but without the Detroit Air episode included. 
Table 1. Calculated Contributions to Secondary Organic Aerosol Formation for the Full Campaign (all normalized to CO).

\begin{tabular}{|c|c|c|c|c|}
\hline & \multicolumn{2}{|c|}{ High $\mathrm{NO}_{\mathrm{x}}$} & \multicolumn{2}{|c|}{ Low $\mathrm{NO}_{\mathrm{x}}$} \\
\hline & $\begin{array}{l}\text { Calculated } \Delta \text { Org } \\
\left(\mu \mathrm{g} \mathrm{m}^{-3} \mathrm{ppbv}^{-1}\right)\end{array}$ & $\begin{array}{c}\text { Fraction of } \\
\text { Observed }(\%)\end{array}$ & $\begin{array}{l}\text { Calculated } \Delta \text { Org } \\
\left(\mu \mathrm{g} \mathrm{m}^{-3} \mathrm{ppbv}^{-1}\right)\end{array}$ & $\begin{array}{c}\text { Fraction of } \\
\text { Observed (\%) }\end{array}$ \\
\hline Benzene-OH & $9.3 \times 10^{-5}$ & 0.2 & $2.8 \times 10^{-4}$ & 0.5 \\
\hline Toluene-OH & $4.1 \times 10^{-4}$ & 0.7 & $2.0 \times 10^{-3}$ & 3.3 \\
\hline $\mathrm{C}_{8}$ Aromatics-OH & $4.6 \times 10^{-4}$ & 0.8 & $3.2 \times 10^{-3}$ & 5.2 \\
\hline Calculated Total Aromatic $\Delta$ Org & $9.6 \times 10^{-4}$ & 1.6 & $5.5 \times 10^{-3}$ & 9.0 \\
\hline Isoprene-OH & $8.4 \times 10^{-3}$ & 13.8 & $7.2 \times 10^{-3}$ & 11.8 \\
\hline Monoterpenes-OH & $6.0 \times 10^{-3}$ & 9.8 & $2.3 \times 10^{-2}$ & 37.7 \\
\hline Monoterpenes- $\mathrm{O}_{3}$ & $7.3 \times 10^{-3}$ & 12.0 & $7.3 \times 10^{-3}$ & 11.9 \\
\hline Calculated Total Biogenic $\Delta$ Org & $2.2 \times 10^{-2}$ & 36.1 & $3.8 \times 10^{-2}$ & 62.3 \\
\hline Calculated Total $\Delta$ Org & $2.3 \times 10^{-2}$ & 37.7 & $4.3 \times 10^{-2}$ & 70.5 \\
\hline Measured $\Delta$ Org & \multicolumn{4}{|c|}{$6.1 \times 10^{-2} \mu \mathrm{g} \mathrm{m}^{-3} \mathrm{ppbv}^{-1}$} \\
\hline
\end{tabular}

Table 2. Calculated Contributions to Secondary Organic Aerosol Formation for the Detroit Air period (all normalized to CO).

\begin{tabular}{l|cc|cc}
\hline & \multicolumn{2}{|c|}{ High NO $_{\mathrm{x}}$} & \multicolumn{2}{c}{ Low NOx } \\
\cline { 2 - 5 } & $\begin{array}{c}\text { Calculated } \Delta \text { Org } \\
\left(\mu \mathrm{g} \mathrm{m}^{-3} \mathrm{ppbv}^{-1}\right)\end{array}$ & $\begin{array}{c}\text { Fraction of } \\
\text { Observed }(\%)\end{array}$ & $\begin{array}{c}\text { Calculated } \Delta \text { Org } \\
\left(\mu \mathrm{g} \mathrm{m}^{-3} \mathrm{ppbv}^{-1}\right)\end{array}$ & $\begin{array}{c}\text { Fraction of } \\
\text { Observed }(\%)\end{array}$ \\
\hline Benzene-OH & $2.7 \times 10^{-4}$ & 0.2 & $5.4 \times 10^{-4}$ & 0.4 \\
Toluene-OH & $1.1 \times 10^{-3}$ & 0.8 & $4.0 \times 10^{-3}$ & 3.1 \\
$\mathrm{C}_{8}$ Aromatics-OH & $9.5 \times 10^{-4}$ & 0.7 & $5.1 \times 10^{-3}$ & 3.9 \\
Calculated Total Aromatic $\Delta$ Org & $2.3 \times 10^{-3}$ & 1.8 & $9.6 \times 10^{-3}$ & 7.4 \\
Isoprene-OH & $1.3 \times 10^{-2}$ & 10.0 & $1.6 \times 10^{-2}$ & 12.3 \\
Monoterpenes-OH & $5.6 \times 10^{-3}$ & 4.3 & $2.1 \times 10^{-2}$ & 16.2 \\
Monoterpenes-O & $4.8 \times 10^{-3}$ & 3.8 & $4.8 \times 10^{-3}$ & 3.7 \\
Calculated Total Biogenic $\Delta$ Org & $2.3 \times 10^{-2}$ & 17.7 & $4.2 \times 10^{-2}$ & 32.3 \\
Calculated Total $\Delta$ Org & $2.5 \times 10^{-2}$ & 19.2 & $5.2 \times 10^{-2}$ & 40.0 \\
Measured $\Delta$ Org & & $1.3 \times 10^{-1} \mu \mathrm{g} \mathrm{m}^{-3} \mathrm{ppbv}^{-1}$ & \\
\hline
\end{tabular}

From Table 1 it is clear that this approach predicts that the biogenic sources of SOA during the BAQS-Met study at Harrow dominate over the aromatic sources. In particular, the source of the biogenics will be the dispersed forests amongst farmland that extend for hundreds of kilometers in southwestern Ontario. An important caveat is that there may be unidentified anthropogenic VOCs that act as SOA precursors as well, such as primary alkanes associated with transportation emissions, so in this work we can only compare the role of biogenics relative to aromatics measured by the PTR-MS, in terms of SOA formation capability.

We recognize that there are uncertainties in the absolute values of the SOA production values that need to be discussed in detail. First, there are uncertainties in the $\mathrm{OH}$ values as described above. Second, an assumption is that the VOC mixing ratios measured at Harrow are representative of those in the surrounding regions in which the daytime pro- duction of SOA is proceeding. With an average wind speed of $3.3 \mathrm{~m} \mathrm{~s}^{-1}$ during the campaign in the daytime time period, this region is very roughly on the order of 70 to $140 \mathrm{~km}$, related to time period of 6 to $12 \mathrm{~h}$ over which the SOA formation occurs. Overall, land usage close to the measurement site is typical of the surrounding terrain, i.e. mostly farmland with interspersed forests of mixed deciduous and coniferous trees, with the notable exception of Windsor/Detroit. Thus, the biogenic measurements at Harrow may be representative of the SOA biogenic precursor fetch. However, the aromatics are likely arising from localized sources. To gain a sense of the variability of such sources, BTEX measurements (Tables S1-S3) illustrate that for the same time periods, measurements in Windsor (part of the Detroit/Windsor metropolitan region) are on average 4.0 times higher for toluene and 2.8 times higher for $\mathrm{C} 8$ aromatics. This gives an upper limit for how significant upwind SOA formation from BTEX may be 
Table 3. Calculated Contributions to Secondary Organic Aerosol Formation for the Full Campaign less the Detroit Air period (all normalized to $\mathrm{CO})$.

\begin{tabular}{l|cc|cc}
\hline & \multicolumn{2}{|c|}{ High NO } & \multicolumn{2}{c}{ Low NO $_{\mathrm{x}}$} \\
\cline { 2 - 5 } & $\begin{array}{c}\text { Calculated } \Delta \text { Org } \\
\left(\mu \mathrm{g} \mathrm{m}^{-3} \mathrm{ppbv}^{-1}\right)\end{array}$ & $\begin{array}{c}\text { Fraction of } \\
\text { Observed }(\%)\end{array}$ & $\begin{array}{c}\text { Calculated } \Delta \text { Org } \\
\left(\mu \mathrm{g} \mathrm{m}^{-3} \mathrm{ppbv}^{-1}\right)\end{array}$ & $\begin{array}{c}\text { Fraction of } \\
\text { Observed }(\%)\end{array}$ \\
\hline Benzene-OH & $5.3 \times 10^{-5}$ & 0.1 & $1.7 \times 10^{-4}$ & 0.3 \\
Toluene-OH & $2.2 \times 10^{-4}$ & 0.4 & $1.2 \times 10^{-3}$ & 1.9 \\
$\mathrm{C}_{8}$ Aromatics-OH & $2.7 \times 10^{-4}$ & 0.4 & $2.0 \times 10^{-3}$ & 3.1 \\
Calculated Total Aromatic $\Delta$ Org & $5.4 \times 10^{-4}$ & 0.8 & $3.4 \times 10^{-3}$ & 5.3 \\
Isoprene-OH & $4.5 \times 10^{-3}$ & 7.0 & $5.4 \times 10^{-3}$ & 8.5 \\
Monoterpenes-OH & $5.1 \times 10^{-3}$ & 6.4 & $2.0 \times 10^{-2}$ & 31.3 \\
Monoterpenes-O & $7.3 \times 10^{-3}$ & 11.4 & $7.3 \times 10^{-3}$ & 11.4 \\
Calculated Total Biogenic $\Delta$ Org & $1.7 \times 10^{-2}$ & 26.5 & $3.3 \times 10^{-2}$ & 51.6 \\
Calculated Total $\Delta$ Org & $1.8 \times 10^{-2}$ & 28.1 & $3.7 \times 10^{-2}$ & 57.8 \\
Measured $\Delta$ Org & \multicolumn{3}{|c}{$6.4 \times 10^{-2} \mu \mathrm{g} \mathrm{m}^{-3} \mathrm{ppbv}^{-1}$} & \\
\hline
\end{tabular}
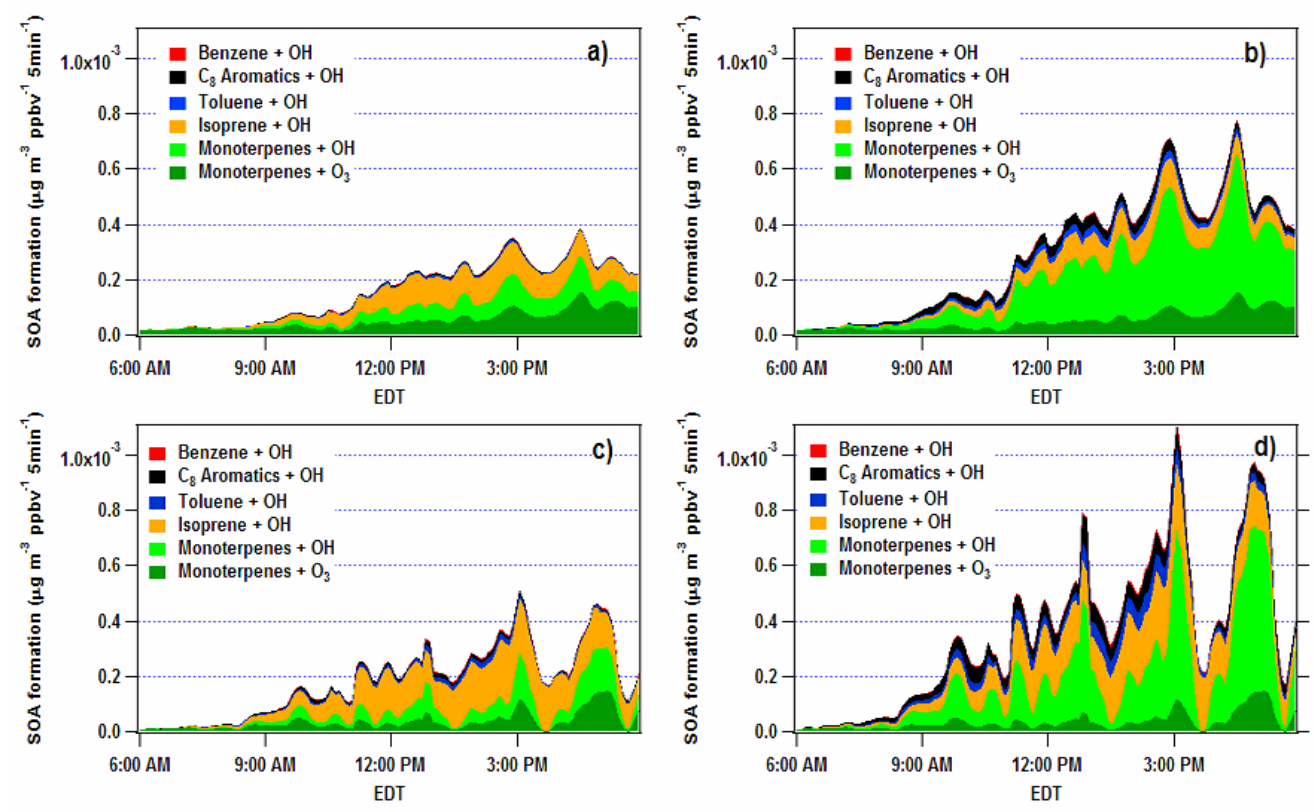

Fig. 10. Amounts of SOA formed per unit time and colored by precursor and oxidant, as calculated using the methods described in the text. (a) Full campaign, high $\mathrm{NO}_{\mathrm{x}}$, (b) full campaign, low $\mathrm{NO}_{\mathrm{x}}$, (c) Detroit air, high $\mathrm{NO}_{\mathrm{x}}$, (d) Detroit air, low $\mathrm{NO}_{\mathrm{x}}$. All data have been normalized to $\mathrm{CO}$.

during the period of Detroit Air. For the rural site Bear Creek to the northeast of Harrow, the measurements were on average a factor of two lower, however. This suggests that in clean conditions, the role of the aromatics may be overestimated using the Harrow values, which may have higher local pollution sources or indirect input from nearby large urban sources.
Third, processes not addressed with this approach include aerosol deposition during the time interval under study. However, aerosol depositional is apparently quite small given the flat diurnal profiles of the CO-normalized HOA PMF factor. The flat diurnal profile indicates that there are no substantial loss processes of particles containing HOA species, either chemical or depositional.

Fourth, we have done the analyses using average values. If, we use median values we find that the predicted SOA closure (i.e. comparison between modeled and measured values) 
is decreased by roughly a factor of two, i.e. roughly $50 \%$ less SOA is generated. This gives some indication of the sensitivity of the calculations to extreme episodes. Tables 2 and 3 provide a further estimate of this uncertainty, where the results without and with the Detroit Air episode are presented. It is seen that the time period without urban outflow is generally similar to the full campaign results, with the degree of closure the same to within $60-70 \%$ and the biogenics dominating as SOA precursors. It should be noted that the derived $\mathrm{OH}$ values used for Table 3, without Detroit Air, are attenuated by $15 \%$ over the total campaign due to lower mean predawn aromatic concentrations. As expected, during Detroit Air, the relative importance of aromatic SOA is enhanced compared to the results when Detroit air is excluded. Interestingly, the absolute amounts of biogenic SOA calculated to form are roughly the same during Detroit outflow as at other times.

Fifth, as with many models, we are only using the SOA yields from processes studied in traditional chamber experiments is occurring and we assume instantaneous formation of SOA after VOC loss. We are not accounting for SOA that might arise from multiphase processes such as carbonyl uptake processes that might occur on acidic particles.

Finally, to address the impact of vertical mixing and role of $\mathrm{CO}$ normalization in this regard, we present results in the Supplementary Information without CO normalization. It is seen that the relative contributions to SOA formation from the biogenics and aromatics remain generally unchanged. The absolute degree of closure of SOA formation amounts improves in high $\mathrm{NO}_{\mathrm{x}}$ scenarios without $\mathrm{CO}$ normalization and in low $\mathrm{NO}_{\mathrm{x}}$ conditions exceeds the observed change in organic mass. Note that without $\mathrm{CO}$ normalization, the diurnal formation of SOA is not as pronounced. We consider the $\mathrm{CO}$ normalization approach to be a more accurate portrayal of the chemistry, however, given the degree to which it shows that relatively long lived species such as benzene and HOA are steady in amount throughout the day.

To gain an additional sense of the level of uncertainties involved, two more calculations are presented. In particular, we also report the calculated and observed integrated formation rates of the sulfate aerosol species. We assume that the formation of sulfate in the afternoon proceeds via $\mathrm{OH}$ chemistry, specifically via the rate-limiting gas-phase reaction of $\mathrm{SO}_{2}$ with the $\mathrm{OH}$ radical. Indeed, the formation rate of sulfate in the afternoon resembles that of organics which are presumably also forming via $\mathrm{OH}$-driven processes. We are not addressing processing that may occur via clouds, which would not have the same diurnal profile. Once ultimately formed from this chemistry, gas-phase sulfuric acid condenses to form aerosol sulfate. This is clearly seen in Fig. 8 where the diurnal analysis indicates a large amount of sulfate production during the photochemically active daytime. Contrary to the organics where the VOC precursors are more uniform both spatially and temporally, $\mathrm{SO}_{2}$ mixing ratios are temporally variable due primarily to passage of sporadic pollution plumes arising from power plants nearby, both in Ontario and the US Midwest. Part of the morning enhancement in $\mathrm{SO}_{2}$ levels may be due to mixing from aloft as the boundary layer breaks up in the morning.

Using the equivalent form of Eq. (1) but with the VOCs replaced by $\mathrm{SO}_{2}$ and with the appropriate gas-phase rate constant (Sander, 2006), the calculated and observed sulfate integrated production rates are: $2.5 \times 10^{-2}$ and $6.2 \times 10^{-2} \mu \mathrm{g} \mathrm{m}^{-3} \mathrm{ppbv}^{-1}$, respectively. We assume that the yield, $Y$, is equal to unity, i.e. all sulfuric acid formed by $\mathrm{SO}_{2}$ oxidation condenses to form AMS-measureable sulfate. The agreement between the calculated and observed sulfate amounts is roughly a factor of two. If the higher estimate of the $\mathrm{OH}$ concentration offered above were used, then the level of agreement would be close to $100 \%$. We believe this degree of agreement provides a level of validation for the general approach that we present with regards to the estimate of $\mathrm{OH}$ levels and the $\mathrm{CO}$ normalization procedure, but it does not address the added factors that affect the yield of organic aerosol, related to its semi-volatile nature and that the yield depends on precursor, oxidation conditions, etc.

As a second evaluation, we performed very simple calculations where we calculate the amount of SOA that would form, when accounting for yield, from the diurnal loss in the normalized aromatic mixing ratios displayed in Fig. 7. For the sum of all the aromatics, we find that the SOA formation amount is essentially the same, to within $4 \%$, as that calculated with the more detailed approach presented in Table 1.

\subsection{Comparison to predictions from an air quality model}

The approach we have presented for the calculation of SOA production amounts is empirically based, relying on simultaneous measurements of VOCs and organic aerosol amounts, and literature values for VOC/oxidant rate constants and SOA yields. It is computationally simple, but has considerable uncertainties associated with it, as outlined above. By contrast, commonly used chemical transport models are highly complex, relying on coupled chemical, emissions and dynamics modules. Although such models are clearly the first choice for modeling organic aerosol formation across a regional domain, it is important that their output can be validated through detailed diagnostic evaluations, i.e. they need to be able to match observations and evaluations of relevant processes at a fixed site as we have done here.

To that end we compare diurnal profiles of AURAMS model predictions and the PTR-MS and AMS measurements at Harrow during BAQS. It is seen in Fig. 11 that the comparison for the gas-phase aromatics is good, especially for the reactive species toluene and the $\mathrm{C}_{8}$ aromatics. On the other hand, the comparison with the biogenic SOA precursors is poor, with substantial levels of isoprene and monoterpenes observed during the day whereas the AURAMS model predicts low levels, likely due to a combination of (1) excessive 

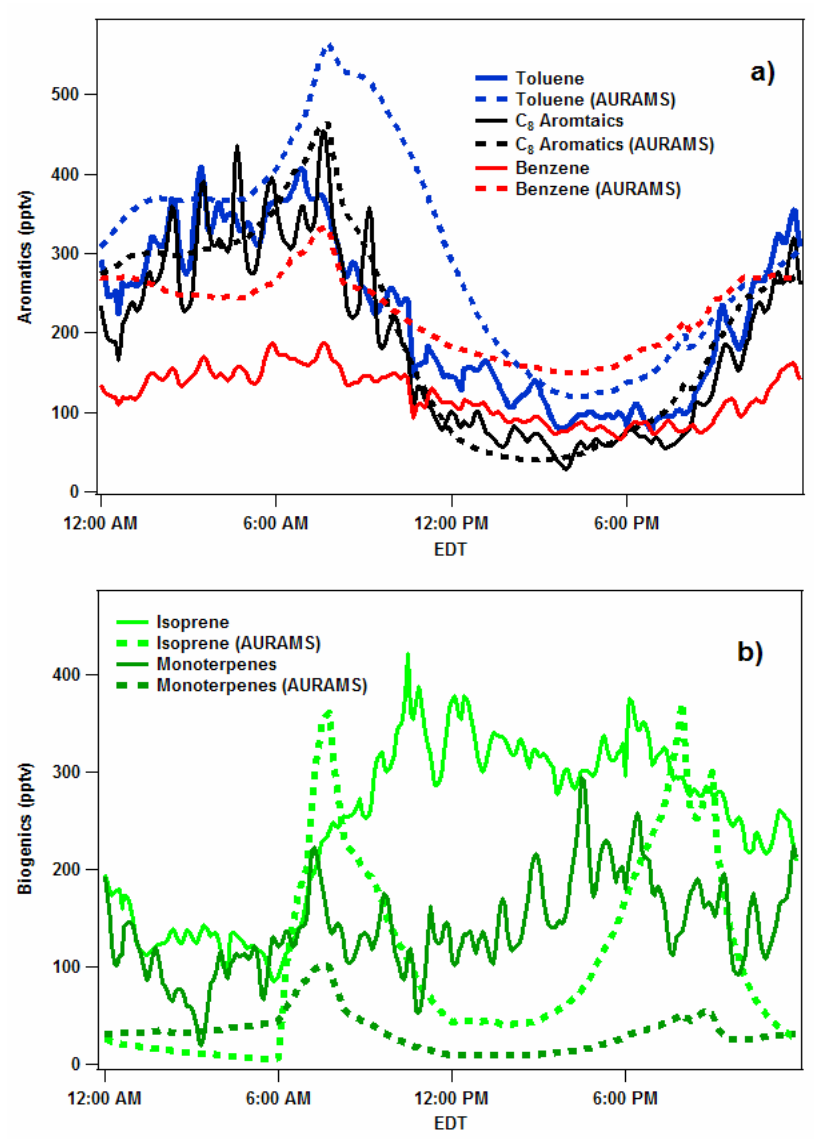

Fig. 11. Diurnal profiles of measured (solid lines) aromatic (a) and biogenic species (b) compared to those from the AURAMS photochemical model (dashed lines).

OH levels within the model, (2) too low local biogenic emissions and/or (3) not enough vertical mixing at dusk and dawn in the model. Finally, the predicted levels of SOA formation during the day (i.e. the increase during the daytime hours) are somewhat lower than those observed at Harrow, likely because of insufficient biogenic SOA contributions (Fig. 12). While we point these differences out, detailed analysis of the source of these inconsistencies within the model are well outside the scope of this paper. Overall, the degree of SOA closure (i.e. to within roughly factors of two to three) from the simple approach presented in this paper is not dissimilar to that for the full chemical transport model.

\section{Summary}

In this paper we have applied a diurnal analysis approach to assess the role of different VOC precursors to the rates of SOA formation at a specific location, where the VOCs are measured by PTR-MS. Measurements were conducted at a rural site in southwestern Ontario subject to a wide variety of air masses during a three-week campaign near summer

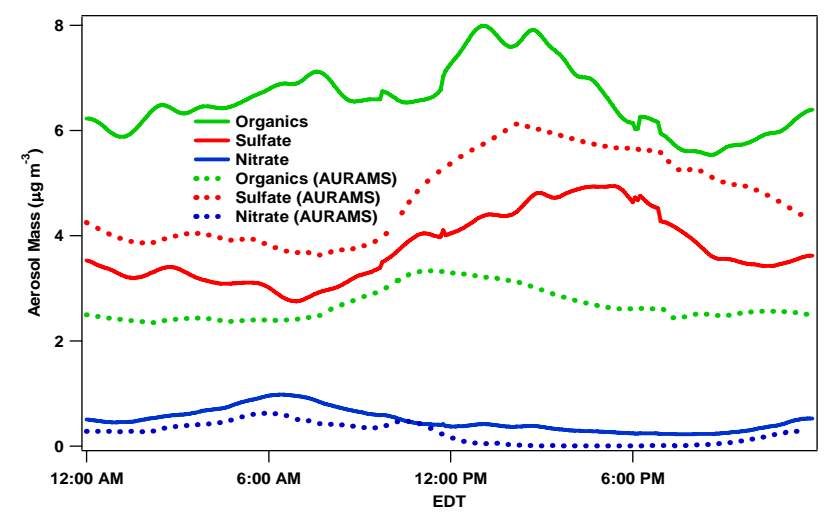

Fig. 12. Comparison between diurnal profiles for AMS measurements (solid lines) and AURAMS predictions (dotted lines).

solstice in 2007. A long-lived tracer, CO, is used to normalize for dynamical effects associated primarily with changing boundary layer height during the day. Integrated production rates of SOA are compared to observed values, as measured by the formation of organic aerosol measured with an AMS. The calculations suggest that biogenic precursors dominate SOA production over aromatic source gases at this site during the full campaign, consistent with continental observations that indicate a large contribution from modern (versus fossil fuel) carbon to SOA (de Gouw and Jimenez, 2009). An important caveat to the relative importance of the biogenics is the possible role of SOA formation from aromatic precursors upwind of the observation site. In particular, by analyzing an individual time period when Detroit outflow was prevalent, we do indeed predict a more substantial role for the aromatics than when this period is excluded from the analysis. By performing analyses on the campaign without Detroit Air we are able to emphasize the importance of biogenic precursors to the local formation rate of SOA at Harrow.

This simple analytic approach has important uncertainties arising from dilution/transport effects that may not be captured by the $\mathrm{CO}$ normalization approach and errors in the estimated $\mathrm{OH}$ concentrations, as described in detail above. Nevertheless, even with these uncertainties, it is intriguing that the degree of SOA closure (i.e. between 38 and $71 \%$ depending on high or low $\mathrm{NO}_{\mathrm{x}}$ conditions with $\mathrm{CO}$ normalization) is quite good given recent reports of large disagreements between measured and modeled levels of organic aerosol (de Gouw and Jimenez, 2009). In particular, agreement between models and measurements in biogenically dominated regimes is comparably good (Capes et al., 2009; Slowik et al., 2010). However, we stress that this comparison between predicted and measured organic aerosol production rates is subject to large uncertainties, for example with the SOA yields from from $\mathrm{OH}+$ Monoterpenes, and that a full chemical transport model is preferred to make such estimates as accurately as possible. 
We propose that measurements of this type, that are now relatively standard (such as those by PTR-MS and AMS, and increasingly $\mathrm{OH}$ ), could be performed at multiple sites across a region to determine the generality of diurnal profiles observed at any one site. If similar, this straightforward approach for estimating secondary aerosol production rates would be validated and thus act as a valuable method for assessing chemical transport model predictions of SOA formation across the same region.

\section{Supplementary material related to this article is available online at: http://www.atmos-chem-phys.net/11/5745/2011/ acp-11-5745-2011-supplement.pdf.}

Acknowledgements. The authors acknowledge the help of G. Evans and research group for housing the AMS in a mobile van during BAQS. Funding for this campaign came through the Ontario Ministry of the Environment, Environment Canada and NSERC. We acknowledge Environment Canada's NAPS program for the canister measurements of BTEX species at Windsor and Bear Creek. We also want to thank Katherine Hayden and Milos Markovic for the use of their airborne $\mathrm{CO}$ and aerosol measurements, and Richard Leaitch for discussions.

Edited by: R. McLaren

\section{References}

Aiken, A. C., Decarlo, P. F., Kroll, J. H., Worsnop, D. R., Huffman, J. A., Docherty, K. S., Ulbrich, I. M., Mohr, C., Kimmel, J. R., Sueper, D., Sun, Y., Zhang, Q., Trimborn, A., Northway, M., Ziemann, P. J., Canagaratna, M. R., Onasch, T. B., Alfarra, M. R., Prevot, A. S. H., Dommen, J., Duplissy, J., Metzger, A., Baltensperger, U., and Jimenez, J. L.: O/C and OM/OC ratios of primary, secondary, and ambient organic aerosols with high-resolution time-of-flight aerosol mass spectrometry, Environ. Sci. Technol., 42, 4478-4485, 2008.

Atkinson, R. and Arey, J.: Gas-phase tropospheric chemistry of biogenic volatile organic compounds: A review, Atmos. Environ., 37, S197-S219, 2003.

Atkinson, R., Baulch, D. L., Cox, R. A., Crowley, J. N., Hampson, R. F., Hynes, R. G., Jenkin, M. E., Rossi, M. J., Troe, J., and IUPAC Subcommittee: Evaluated kinetic and photochemical data for atmospheric chemistry: Volume II - gas phase reactions of organic species, Atmos. Chem. Phys., 6, 3625-4055, doi:10.5194/acp-6-3625-2006, 2006.

Capes, G., Murphy, J. G., Reeves, C. E., McQuaid, J. B., Hamilton, J. F., Hopkins, J. R., Crosier, J., Williams, P. I., and Coe, H.: Secondary organic aerosol from biogenic VOCs over West Africa during AMMA, Atmos. Chem. Phys., 9, 3841-3850, doi:10.5194/acp-9-3841-2009, 2009.

Chen, J. J., Mao, H. T., Talbot, R. W., and Griffin, R. J.: Application of the CACM and MPMPO modules using the CMAQ model for the eastern united states, J. Geophys. Res.-Atmos., 111, D23s25, doi:10.1029/2006jd007603, 2006. de Gouw, J. and Jimenez, J. L.: Organic aerosols in the Earth's atmosphere, Environ. Sci. Technol., 43, 7614-7618, 2009.

de Gouw, J. and Warneke, C.: Measurements of volatile organic compounds in the Earth's atmosphere using proton-transferreaction mass spectrometry, Mass Spectrom. Rev., 26, 223-257, 2007.

de Gouw, J. A., Middlebrook, A. M., Warneke, C., Goldan, P. D., Kuster, W. C., Roberts, J. M., Fehsenfeld, F. C., Worsnop, D. R., Canagaratna, M. R., Pszenny, A. A. P., Keene, W. C., Marchewka, M., Bertman, S. B., and Bates, T. S.: Budget of organic carbon in a polluted atmosphere: Results from the New England air quality study in 2002, J. Geophys. Res.-Atmos., 110, D16305, doi:10.1029/2004jd005623, 2005.

de Gouw, J. A., Brock, C. A., Atlas, E. L., Bates, T. S., Fehsenfeld, F. C., Goldan, P. D., Holloway, J. S., Kuster, W. C., Lerner, B. M., Matthew, B. M., Middlebrook, A. M., Onasch, T. B., Peltier, R. E., Quinn, P. K., Senff, C. J., Stohl, A., Sullivan, A. P., Trainer, M., Warneke, C., Weber, R. J., and Williams, E. J.: Sources of particulate matter in the northeastern United States in summer: 1. Direct emissions and secondary formation of organic matter in urban plumes, J. Geophys. Res.-Atmos., 113, D08301, doi:10.1029/2007jd009243, 2008.

de Gouw, J. A., Welsh-Bon, D., Warneke, C., Kuster, W. C., Alexander, L., Baker, A. K., Beyersdorf, A. J., Blake, D. R., Canagaratna, M., Celada, A. T., Huey, L. G., Junkermann, W., Onasch, T. B., Salcido, A., Sjostedt, S. J., Sullivan, A. P., Tanner, D. J., Vargas, O., Weber, R. J., Worsnop, D. R., Yu, X. Y., and Zaveri, R.: Emission and chemistry of organic carbon in the gas and aerosol phase at a sub-urban site near Mexico City in March 2006 during the MILAGRO study, Atmos. Chem. Phys., 9, 3425-3442, doi:10.5194/acp-9-3425-2009, 2009.

Drewnick, F., Hings, S. S., DeCarlo, P., Jayne, J. T., Gonin, M., Fuhrer, K., Weimer, S., Jimenez, J. L., Demerjian, K. L., Borrmann, S., and Worsnop, D. R.: A new time-of-flight aerosol mass spectrometer (ToF-AMS) - instrument description and first field deployment, Aerosol Sci. Technol., 39, 637-658, 2005.

Gong, S. L., Barrie, L. A., Blanchet, J. P., von Salzen, K., Lohmann, U., Lesins, G., Spacek, L., Zhang, L. M., Girard, E., Lin, H., Leaitch, R., Leighton, H., Chylek, P., and Huang, P.: Canadian aerosol module: A size-segregated simulation of atmospheric aerosol processes for climate and air quality models 1. Module development, J. Geophys. Res.-Atmos., 108, 4007, doi:10.1029/2001jd002002, 2003.

Hallquist, M., Wenger, J. C., Baltensperger, U., Rudich, Y., Simpson, D., Claeys, M., Dommen, J., Donahue, N. M., George, C., Goldstein, A. H., Hamilton, J. F., Herrmann, H., Hoffmann, T., Iinuma, Y., Jang, M., Jenkin, M. E., Jimenez, J. L., Kiendler-Scharr, A., Maenhaut, W., McFiggans, G., Mentel, Th. F., Monod, A., Prévôt, A. S. H., Seinfeld, J. H., Surratt, J. D., Szmigielski, R., and Wildt, J.: The formation, properties and impact of secondary organic aerosol: current and emerging issues, Atmos. Chem. Phys., 9, 5155-5236, doi:10.5194/acp-95155-2009, 2009.

Hao, L. Q., Romakkaniemi, S., Yli-Pirilä, P., Joutsensaari, J., Kortelainen, A., Kroll, J. H., Miettinen, P., Vaattovaara, P., Tiitta, P., Jaatinen, A., Kajos, M. K., Holopainen, J. K., Heijari, J., Rinne, J., Kulmala, M., Worsnop, D. R., Smith, J. N., and Laaksonen, A.: Mass yields of secondary organic aerosols from the oxidation of $\alpha$-pinene and real plant emissions, Atmos. Chem. Phys., 11, 
1367-1378, doi:10.5194/acp-11-1367-2011, 2011.

Heald, C. L., Jacob, D. J., Park, R. J., Russell, L. M., Huebert, B. J., Seinfeld, J. H., Liao, H., and Weber, R. J.: A large organic aerosol source in the free troposphere missing from current models, Geophys. Res. Lett., 32, L18809, doi:10.1029/2005g1023831, 2005.

Henze, D. K. and Seinfeld, J. H.: Global secondary organic aerosol from isoprene oxidation, Geophys. Res. Lett., 33, L09812, doi:10.1029/2006g1025976, 2006.

Hildebrandt, L., Donahue, N. M., and Pandis, S. N.: High formation of secondary organic aerosol from the photo-oxidation of toluene, Atmos. Chem. Phys., 9, 2973-2986, doi:10.5194/acp-92973-2009, 2009.

Hurley, M. D., Sokolov, O., Wallington, T. J., Takekawa, H., Karasawa, M., Klotz, B., Barnes, I., and Becker, K. H.: Organic aerosol formation during the atmospheric degradation of toluene, Environ. Sci. Technol., 35, 1358-1366, 2001.

Jang, M. S. and Kamens, R. M.: Characterization of secondary aerosol from the photooxidation of toluene in the presence of $\mathrm{NO}_{\mathrm{x}}$ and 1-propene, Environ. Sci. Technol., 35, 3626-3639, 2001.

Jayne, J. T., Leard, D. C., Zhang, X. F., Davidovits, P., Smith, K. A., Kolb, C. E., and Worsnop, D. R.: Development of an aerosol mass spectrometer for size and composition analysis of submicron particles, Aerosol Sci. Technol., 33, 49-70, 2000.

Jimenez, J. L., Jayne, J. T., Shi, Q., Kolb, C. E., Worsnop, D. R., Yourshaw, I., Seinfeld, J. H., Flagan, R. C., Zhang, X. F., Smith, K. A., Morris, J. W., and Davidovits, P.: Ambient aerosol sampling using the aerodyne aerosol mass spectrometer, J. Geophys. Res.-Atmos., 108, 8425, doi:10.1029/2001JD001213, 2003.

Jimenez, J. L., Canagaratna, M. R., Donahue, N. M., Prevot, A. S. H., Zhang, Q., Kroll, J. H., DeCarlo, P. F., Allan, J. D., Coe, H., Ng, N. L., Aiken, A. C., Docherty, K. S., Ulbrich, I. M., Grieshop, A. P., Robinson, A. L., Duplissy, J., Smith, J. D., Wilson, K. R., Lanz, V. A., Hueglin, C., Sun, Y. L., Tian, J., Laaksonen, A., Raatikainen, T., Rautiainen, J., Vaattovaara, P., Ehn, M., Kulmala, M., Tomlinson, J. M., Collins, D. R., Cubison, M. J., Dunlea, E. J., Huffman, J. A., Onasch, T. B., Alfarra, M. R., Williams, P. I., Bower, K., Kondo, Y., Schneider, J., Drewnick, F., Borrmann, S., Weimer, S., Demerjian, K., Salcedo, D., Cottrell, L., Griffin, R., Takami, A., Miyoshi, T., Hatakeyama, S., Shimono, A., Sun, J. Y., Zhang, Y. M., Dzepina, K., Kimmel, J. R., Sueper, D., Jayne, J. T., Herndon, S. C., Trimborn, A. M., Williams, L. R., Wood, E. C., Middlebrook, A. M., Kolb, C. E., Baltensperger, U., and Worsnop, D. R.: Evolution of organic aerosols in the atmosphere, Science, 326, 1525-1529, doi:10.1126/science.1180353, 2009.

Kleeman, M. J., Ying, Q., Lu, J., Mysliwiec, M. J., Griffin, R. J., Chen, J. J., and Clegg, S.: Source apportionment of secondary organic aerosol during a severe photochemical smog episode, Atmos. Environ., 41, 576-591, 2007.

Kleindienst, T. E., Lewandowski, M., Offenberg, J. H., Jaoui, M., and Edney, E. O.: The formation of secondary organic aerosol from the isoprene $+\mathrm{OH}$ reaction in the absence of $\mathrm{NO}_{\mathrm{x}}$, Atmos. Chem. Phys., 9, 6541-6558, doi:10.5194/acp-9-6541-2009, 2009.

Kleinman, L. I., Daum, P. H., Lee, Y. N., Senum, G. I., Springston, S. R., Wang, J., Berkowitz, C., Hubbe, J., Zaveri, R. A., Brechtel, F. J., Jayne, J., Onasch, T. B., and Worsnop, D.: Aircraft observations of aerosol composition and ageing in new england and mid-atlantic states during the summer 2002 New England air quality study field campaign, J. Geophys. Res.-Atmos., 112, D09310, doi:10.1029/2006jd007786, 2007.

Kroll, J. H. and Seinfeld, J. H.: Chemistry of secondary organic aerosol: Formation and evolution of low-volatility organics in the atmosphere, Atmos. Environ., 42, 3593-3624, 2008.

Kroll, J. H., Ng, N. L., Murphy, S. M., Flagan, R. C., and Seinfeld, J. H.: Secondary organic aerosol formation from isoprene photooxidation, Environ. Sci. Technol., 40, 1869-1877, 2006.

Levy, I., Makar, P. A., Sills, D., Zhang, J., Hayden, K. L., Mihele, C., Narayan, J., Moran, M. D., Sjostedt, S., and Brook, J.: Unraveling the complex local-scale flows influencing ozone patterns in the southern Great Lakes of North America, Atmos. Chem. Phys., 10, 10895-10915, doi:10.5194/acp-10-10895-2010, 2010.

Li, Q. B., Jacob, D. J., Munger, J. W., Yantosca, R. M., and Parrish, D. D.: Export of noy from the north american boundary layer: Reconciling aircraft observations and global model budgets, J. Geophys. Res.-Atmos., 109, D02313, doi:10.1029/2003jd004086, 2004.

Lindinger, W., Hansel, A., and Jordan, A.: Proton-transfer-reaction mass spectrometry (PTR-MS): On-line monitoring of volatile organic compounds at pptv levels, Chem. Soc. Rev., 27, 347-354, 1998.

Makar, P. A., Moran, M. D., Zheng, Q., Cousineau, S., Sassi, M., Duhamel, A., Besner, M., Davignon, D., Crevier, L.-P., and Bouchet, V. S.: Modelling the impacts of ammonia emissions reductions on North American air quality, Atmos. Chem. Phys., 9, 7183-7212, doi:10.5194/acp-9-7183-2009, 2009.

Murphy, B. N. and Pandis, S. N.: Simulating the formation of semivolatile primary and secondary organic aerosol in a regional chemical transport model, Environ. Sci. Technol., 43, 47224728, 2009.

Ng, N. L., Chhabra, P. S., Chan, A. W. H., Surratt, J. D., Kroll, J. H., Kwan, A. J., McCabe, D. C., Wennberg, P. O., Sorooshian, A., Murphy, S. M., Dalleska, N. F., Flagan, R. C., and Seinfeld, J. H.: Effect of $\mathrm{NO}_{\mathrm{x}}$ level on secondary organic aerosol (SOA) formation from the photooxidation of terpenes, Atmos. Chem. Phys., 7, 5159-5174, doi:10.5194/acp-7-5159-2007, 2007a.

Ng, N. L., Kroll, J. H., Chan, A. W. H., Chhabra, P. S., Flagan, R. C., and Seinfeld, J. H.: Secondary organic aerosol formation from m-xylene, toluene, and benzene, Atmos. Chem. Phys., 7, 3909-3922, doi:10.5194/acp-7-3909-2007, 2007b.

Paatero, P.: Least squares formulation of robust non-negative factor analysis, Chemometrics Intell. Lab. Syst., 37, 23-35, 1997.

Paatero, P. and Tapper, U.: Positive matrix factorization - a nonnegative factor model with optimal utilization of error-estimates of data values, Environmetrics, 5, 111-126, 1994.

Pankow, J. F.: An absorption-model of gas-particle partitioning of organic-compounds in the atmosphere, Atmos. Environ., 28, 185-188, 1994.

Parrish, D. D., Ryerson, T. B., Holloway, J. S., Neuman, J. A., Roberts, J. M., Williams, J., Stroud, C. A., Frost, G. J., Trainer, M., Hubler, G., Fehsenfeld, F. C., Flocke, F., and Weinheimer, A. J.: Fraction and composition of $\mathrm{NO}_{y}$ transported in air masses lofted from the North American continental boundary layer, J. Geophys. Res.-Atmos., 109, D09302, doi:10.1029/2003jd004226, 2004.

Roberts, J. M., Fehsenfeld, F. C., Liu, S. C., Bollinger, M. J., Hahn, 
C., Albritton, D. L., and Sievers, R. E.: Measurements of aromatic hydrocarbon ratios and $\mathrm{NO}_{\mathrm{x}}$ concentrations in the rural troposphere - observation of air-mass photochemical aging and $\mathrm{NO}_{\mathrm{x}}$ removal, Atmos. Environ., 18, 2421-2432, 1984.

Robinson, A. L., Donahue, N. M., Shrivastava, M. K., Weitkamp, E. A., Sage, A. M., Grieshop, A. P., Lane, T. E., Pierce, J. R., and Pandis, S. N.: Rethinking organic aerosols: Semivolatile emissions and photochemical aging, Science, 315, 1259-1262, doi:10.1126/science.1133061, 2007.

Sander, S.: Chemical kinetics and photochemical data for use in atmospheric studies, Evaluation Number 15, NASA, JPL, 2006.

Schauer, J. J., Kleeman, M. J., Cass, G. R., and Simoneit, B. R. T.: Measurement of emissions from air pollution sources. 2. $\mathrm{C}_{1}$ through $\mathrm{C}_{30}$ organic compounds from medium duty diesel trucks, Environ. Sci. Technol., 33, 1578-1587, 1999.

Schauer, J. J., Kleeman, M. J., Cass, G. R., and Simoneit, B. R. T.: Measurement of emissions from air pollution sources. 5. $\mathrm{C}_{1}$ $-\mathrm{C}_{32}$ organic compounds from gasoline-powered motor vehicles, Environ. Sci. Technol., 36, 1169-1180, 2002.

Seinfeld, J. H. and Pankow, J. F.: Organic atmospheric particulate material, Annu. Rev. Phys. Chem., 54, 121-140, 2003.

Shilling, J. E., Chen, Q., King, S. M., Rosenoern, T., Kroll, J. H., Worsnop, D. R., McKinney, K. A., and Martin, S. T.: Particle mass yield in secondary organic aerosol formed by the dark ozonolysis of $\alpha$-pinene, Atmos. Chem. Phys., 8, 2073-2088, doi:10.5194/acp-8-2073-2008, 2008.

Slowik, J. G., Stroud, C., Bottenheim, J. W., Brickell, P. C., Chang, R. Y.-W., Liggio, J., Makar, P. A., Martin, R. V., Moran, M. D., Shantz, N. C., Sjostedt, S. J., van Donkelaar, A., Vlasenko, A., Wiebe, H. A., Xia, A. G., Zhang, J., Leaitch, W. R., and Abbatt, J. P. D.: Characterization of a large biogenic secondary organic aerosol event from eastern Canadian forests, Atmos. Chem. Phys., 10, 2825-2845, doi:10.5194/acp-10-2825-2010, 2010.

Slowik, J. G., Brook, J., Chang, R. Y.-W., Evans, G. J., Hayden, K., Jeong, C.-H., Li, S.-M., Liggio, J., Liu, P. S. K., McGuire, M., Mihele, C., Sjostedt, S., Vlasenko, A., and Abbatt, J. P. D.: Photochemical processing of organic aerosol at nearby continental sites: contrast between urban plumes and regional aerosol, Atmos. Chem. Phys., 11, 2991-3006, doi:10.5194/acp-11-29912011, 2011.

Stroud, C. A., Morneau, G., Makar, P. A., Moran, M. D., Gong, W., Pabla, B., Zhang, J., Bouchet, V. S., Fox, D., Venkatesh, S., Wang, D., and Dann, T.: OH-reactivity of volatile organic compounds at urban and rural sites across canada: Evaluation of air quality model predictions using speciated VOC measurements, Atmos. Environ., 42, 7746-7756, 2008.
Stroud, C. A., Makar, P. A., Moran, M. D., Gong, W., Gong, S., Zhang, J., Hayden, K., Mihele, C., Brook, J. R., Abbatt, J. P. D., and Slowik, J. G.: Impact of model grid spacing on regionaland urban- scale air quality predictions of organic aerosol, Atmos. Chem. Phys., 11, 3107-3118, doi:10.5194/acp-11-31072011, 2011.

Ulbrich, I. M., Canagaratna, M. R., Zhang, Q., Worsnop, D. R., and Jimenez, J. L.: Interpretation of organic components from Positive Matrix Factorization of aerosol mass spectrometric data, Atmos. Chem. Phys., 9, 2891-2918, doi:10.5194/acp-9-2891-2009, 2009.

Vlasenko, A., Slowik, J. G., Bottenheim, J. W., Brickell, P. C., Chang, R. Y. W., Macdonald, A. M., Shantz, N. C., Sjostedt, S. J., Wiebe, H. A., Leaitch, W. R., and Abbatt, J. P. D.: Measurements of VOCs by proton transfer reaction mass spectrometry at a rural Ontario site: Sources and correlation to aerosol composition, J. Geophys. Res.-Atmos., 114, D21305, doi:10.1029/2009jd012025, 2009.

Volkamer, R., Jimenez, J. L., San Martini, F., Dzepina, K., Zhang, Q., Salcedo, D., Molina, L. T., Worsnop, D. R., and Molina, M. J.: Secondary organic aerosol formation from anthropogenic air pollution: Rapid and higher than expected, Geophys. Res. Lett., 33, L17811, doi:10.1029/2006GL026899, 2006.

Wang, D., Fuentes, J. D., Travers, D., Dann, T., and Connolly, T.: Non-methane hydrocarbons and carbonyls in the lower Fraser valley during Pacific 2001, Atmos. Environ., 39, 5261-5272, 2005.

Zhang, Q., Jimenez, J. L., Canagaratna, M. R., Allan, J. D., Coe, H., Ulbrich, I., Alfarra, M. R., Takami, A., Middlebrook, A. M., Sun, Y. L., Dzepina, K., Dunlea, E., Docherty, K., DeCarlo, P. F., Salcedo, D., Onasch, T., Jayne, J. T., Miyoshi, T., Shimono, A., Hatakeyama, S., Takegawa, N., Kondo, Y., Schneider, J., Drewnick, F., Borrmann, S., Weimer, S., Demerjian, K., Williams, P., Bower, K., Bahreini, R., Cottrell, L., Griffin, R. J., Rautiainen, J., Sun, J. Y., Zhang, Y. M., and Worsnop, D. R.: Ubiquity and dominance of oxygenated species in organic aerosols in anthropogenically-influenced northern hemisphere midlatitudes, Geophys. Res. Lett., 34, L13801, doi:10.1029/2007GL029979, 2007. 